\section{Behavioral interventions to promote condom use among women living with HIV: a systematic review update}

\author{
Intervenções comportamentais para promover o \\ uso de preservativo entre mulheres vivendo com \\ HIV: atualização de uma revisão sistemática
}

\section{Intervenciones conductuales para promover el uso del condón entre las mujeres que viven con el VIH: actualización de una revisión sistemática}

\begin{abstract}
Behavioral interventions have been essential components of HIV prevention approaches, especially those aimed to promote safe sexual practices. We conducted a comprehensive literature search without language restrictions between 1980 and July 2014 to identify randomized controlled trials or controlled studies investigating behavioral interventions which: included women living with HIV; focused on condom use promotion; presented/analyzed outcomes by gender; used a 3-month follow-up or more; and considered at least one HIV-related behavioral or biological outcome. Eight studies comprising a total of 1,355 women living with HIV were included in the meta-analyses, and 13 studies were qualitatively described. When compared to standard care or minimal support intervention, behavioral interventions did not demonstrate an effect on increasing consistent condom use at the 3-month follow-up $(R R=0.92 ; 95 \% C I: 0.73,1.16 ; p=0.48)$, 6-month follow-up $(R R=1.13 ; 95 \% C I: 0.96,1.34 ; p=0.15)$, and 12-month follow-up $(R R=0.91 ;$ 95\%CI: 0.77, 1.08; $p=0.30$ ). Behavioral interventions also failed to reach positive effect in reduction of unprotected sexual intercourse at 6 months $(M D=-1.80 ; 95 \% C I:-4.21,0.62 ; p=0.14)$ and 12-months follow-up $(M D=-1.39 ; 95 \% C I:-2.29,0.21 ; p=0.09)$. These findings should be interpreted with caution since they are based on a few small trials. New researches are needed to assess the potential gains from a combination of interventions that promote safe sexual behavior with a harm reduction and gender approach, particularly in developing countries where HIV infection rates remain high.
\end{abstract}

Clinical Trial; Sexual Behavior; HIV; Women
Tonantzin Ribeiro Gonçalves 1

Evelise Rigoni Faria 2

Fernanda Torres de Carvalho 3

Cesar Augusto Piccinini 4

Jean Anne Shoveller 5

doi: 10.1590/0102-311X00202515

\section{Correspondence}

T. R. Gonçalves

Rua Canísio Binsfeld 271, Porto Alegre, RS 91788-060, Brasil. tonanrib@yahoo.com.br

1 Pós-graduação em Saúde Coletiva, Universidade do Vale do Rio dos Sinos, São Leopoldo, Brasil.

2 Grupo Hospitalar Conceição, Porto Alegre, Brasil.

3 Ambulatório de Dermatologia Sanitária, Secretaria Estadual da Saúde do Rio Grande do Sul, Porto Alegre, Brasil. 4 Programa de Pós-graduação em Psicologia, Universidade Federal do Rio Grande do Sul, Porto Alegre, Brasil. 5 School of Population es Public Health, University of British Columbia, Vancouver, Canada. 


\section{Background}

HIV infection rates among women increased greatly in the 1990s and have remained stable since then. In 2014, women accounted for half of the 36.9 million cases of HIV infection in the world, mainly as a result of heterosexual transmission 1. Southern Africa is the epicenter of an epidemic marked by profound gender inequality, with HIV infection rates in women up to eight times higher than in men 2. In Brazil, 35\% of all AIDS cases reported in 2013 were in women (13,934 out of 39,501), or a female-to-male ratio of 1:1.8 for persons living with AIDS 3 .

The large number of HIV cases in women has dramatic public health consequences. Women face challenges to interrupt the HIV transmission chain, prevent mother-to-child transmission, and maintain their own health. These challenges directly affect their sexual practices. Women living with HIV are at increased risk for sexually transmitted infections (STI) 4,5, cervical dysplasia, and genital cancer 6,7. Concurrent STI and HIV also increase the risk of female-to-male HIV transmission during sexual intercourse 5 and the risk of mother-to-child HIV transmission by pregnant women. Furthermore, some STI during pregnancy pose potential risk of congenital problems, for example maternal syphilis 8 .

Healthy sexual behaviors are important buffers against the challenges faced by women living with HIV. Protected sexual intercourse through consistent condom use has been described as the most effective way to prevent both STI and HIV transmission ${ }^{9}$. Despite positive advances (expansion of treatment and HIV testing) showed in the " 15 by 15 " report 10 of the Global AIDS Response, sex protected by condom use remains a challenge. The focus on treatment as prevention has achieved recognized success; however, detectable HIV viral loads and imperfect adherence to antiretroviral therapy (ART) were not uncommon. Barrier methods such as condoms remain necessary to achieve broad reduction in HIV and other STI 11,12, considering that sexual transmission is responsible for most of new HIV cases 9 .

Among women, although the prevalence of sexual risk behavior generally declines after HIV diagnosis, a substantial group (30-40\%) continues to engage in unprotected sexual intercourse 13,14 . Women are also less likely to use a condom when they have an HIV-infected partner than when the partners are HIV-negative or with unknown HIV status. Findings from a cross-sectional study including 978 women showed that $51 \%$ of unprotected sexual intercourse among HIV-infected women in the previous three months involved an HIV-infected partner (30\% of unprotected sexual intercourse occurred with an HIV-uninfected partner, and 26\% with a partner of unknown status) 14 . Studies also reported higher levels of unprotected sex among women after ART initiation when compared to women before treatment initiation, independently of therapeutic response 15 , suggesting that beliefs regarding lower levels of infectivity under ART are also associated with less frequent condom use.

In addition to these findings, it is crucial to highlight the social determinants surrounding unprotected sexual behavior in women. Gender inequities have been cited as the main reason for unprotected sexual practices among women living with HIV 10,12,16, including precarious socioeconomic conditions, low educational level, gendered power imbalances, intimate partner violence, and partner alcohol abuse. Reproductive intentions have also been emphasized as a reason for not using condoms 17.

In order to avoid sexual risk behavior, programs for social and behavioral change have been encouraged and are seen as an essential component of HIV prevention approaches 18 . The effectiveness of such prevention programs in increasing condom use and preventing HIV infection was demonstrated in a previous meta-analysis with HIV-seronegative participants 19 . Considering people living with HIV, behavioral interventions have focused on reducing sexual risk behaviors and coping with other challenges of living with HIV 20,21. Behavioral interventions to increase antiretroviral adherence 22, disclosure of HIV diagnosis to sex partners 23 , and promotion of mental health 24 have shown promising results. Regarding sexual risk behaviors, studies showed that behavioral interventions can reduce unprotected sexual practices among people living with HIV 25,26. The effectiveness is also attested by meta-analyses, especially when intervention includes skills training 21,27 . Interventions guided by longer and more intensive behavioral theories were found to be more effective at promoting protected sexual intercourse. One-to-one interventions by healthcare providers in medical care settings were also associated with a reduction in unprotected sex 6 . 
Women living with HIV should be the target population for behavioral interventions, especially in countries with high HIV prevalence. These interventions must be based on a clear understanding of the social and cultural contexts shaping sexual behavior ${ }^{18}$. Findings thus suggest that interventions addressing gender-specific issues, power imbalances, and culturally relevant information are more successful in reducing HIV transmission risk behavior among women living with HIV 12,28,29. Although an emerging body of evidence indicates that behavioral interventions can be effective, few studies have focused on women living with HIV. The absence of solid evidence in this area presents a gap in the field of prevention for this population. A previous meta-analysis investigated the effectiveness of behavioral interventions on promoting condom use among women living with HIV 30 . The pooled analysis of five randomized controlled trials found little effect on behavioral interventions at promoting consistent condom use among HIV-positive women. Since these findings were based on a few small trials, the present study aimed to update and broaden this previous systematic review and meta-analysis 30 in order to better understand the intervention effects on protected sexual behavior in women living with HIV.

Just three years after the original systematic review was performed, several relevant studies were published. Considering the low quality of the evidence found on behavioral interventions to promote condom use among women living with HIV, an update was expected to provide a more accurate picture of these interventions and their implications for public health research and decision-making. Some methodological shortcomings in the initial review could also be addressed (e.g., being based only on a dichotomous outcome, with few studies to conduct subgroup analyses), thereby expanding the findings. Finally, this update review aimed to critically describe and discuss all relevant behavioral interventions to promote condom use among women living with HIV, regardless of whether the study provided data for inclusion in the meta-analysis.

\section{Methods}

Since the current study aimed to update a previous review, we replicated the same methodological procedures described in Carvalho et al. 30 and summarized as follows. We searched the following electronic databases regardless of language or publication status using the optimal sensitive search strategy developed by the Cochrane Collaboration 31: (1) Cochrane Central Register of Controlled Trials (CENTRAL); (2) MEDLINE (PubMed); (3) EMBASE; (4) Latin American and Caribbean Health Sciences Literature (LILACS); (5) PsycInfo; (6) Social Science Citation Index (SocINDEX); and (7) Cumulative Index to Nursing and Allied Health Literature (CINAHL) through EBSCO. The previous search covered the period between January 1980 and May 2010, and this review used specific search terms to identify relevant studies from May 2010 to July 2014. We also examined reference lists from all pertinent reviews and published studies; we searched for unpublished studies in the WHO International Clinical Trials Registry Platform and the Clinicaltrials.gov database and in the International AIDS Conferences, National HIV Prevention Conference (through the Meeting Abstracts Database - NLM Gateway), the International Society for Sexually Transmitted Disease Research, and the Conference on HIV Pathogenesis and Treatment (through the conference websites). Finally, we contacted experts in the field for recommendations on additional intervention research reports and unpublished sources.

A systematic review and meta-analysis were conducted following the Cochrane Collaboration methods 31. Studies included were randomized trials (RCT) or controlled studies (CCT) investigating HIV or STI behavioral interventions designed for people living with HIV which: (1) included HIVpositive women; (2) focused on condom use promotion; (3) presented outcomes by gender or reported having performed analyses by gender; (4) provided sufficient data to calculate effect sizes (in the metaanalysis portion); and (5) used a 3-month follow-up or more. Interventions could focus on providing information, counseling, health education, emotional well-being, skills training, coping strategies, or peer education related to HIV risk behaviors. There were no restrictions to the intervention's theoretical approach, setting, frequency, or duration. Protected sexual intercourse (or consistent condom use) was described as use of condoms in all vaginal, anal, or oral sexual relations with casual and/or steady partners. All other situations were considered inconsistent condom use (e.g., condom 
use "almost always" or "sometimes"). This update included a new outcome (reduction in unprotected sexual intercourse - continuous outcome).

The search was completed by one of the authors (T.R.G.). Citations retrieved from electronic searches were inspected by two authors (F.T.C. and E.R.F.) who independently screened studies for inclusion. Uncertainties were resolved by consensus. Following an initial screening, all potentially eligible studies were independently read by at least two authors (E.R.F., F.T.C., or T.R.G.) who assessed in detail the study design, types of participants, types of interventions, and outcome measures. Kappa coefficient indicated good agreement between reviewers both in the first review version $(\mathrm{k}=0.76)$ and in the updated version $(\mathrm{k}=0.69)$.

Using a standardized data extraction form, E.R.F., F.T.C., and T.R.G. extracted the following characteristics from each study that met the inclusion criteria: (1) description of study participants (e.g., sample size, demographic characteristics, country where the study was performed); (2) eligibility criteria for enrolment (e.g., HIV+ diagnosis); (3) details of the intervention (e.g., length of intervention and follow-up, individual or group modality, behavioral techniques); (4) assessment of risk of bias (e.g., study design, generation of allocation sequence, allocation concealment, blinding, loss to followup, inclusion of all randomized participants, and incomplete outcome data addressed); (5) outcome measures (e.g., acquisition of STIs or hepatitis B, self-reported protected anal, vaginal, or oral sexual intercourse); and (6) data analysis strategy.

Methodological quality was assessed through RevMan 5 (Cochrane Tech; http://tech.cochrane. org/revman/download) in accordance with the recommendations of the Cochrane Handbook of Systematic Reviews of Interventions 31. Risk of bias was categorized as "low risk", "high risk", or "unclear" and was listed in risk of bias tables separated by trial. We contacted the studies' authors to obtain additional information on missing data. Finally, the GRADE system was used to evaluate the overall quality of evidence for the outcome 32,33 .

Statistical analysis was conducted according to Cochrane guidelines for systematic reviews of distinct treatments 31 . For dichotomous outcomes (consistent versus inconsistent condom use), the absolute numbers of participants reporting consistent condom use in each group (intervention and control) were extracted. The results for each intervention's effect were expressed as risk ratios (RR) with 95\% confidence intervals (95\% CI) and were combined for meta-analysis. For the continuous outcome (reduction in unprotected sexual acts), mean and standard deviations of condom use during sexual intercourse (relative frequency) for intervention and control groups were obtained. The difference in means (MD) and respective 95\%CI were used to measure the absolute difference between the means in interventions and comparison groups. Since one included study was a cluster randomized trial, we used values of the intra-class correlation coefficient reported in a previous publication related to this intervention 34 to adjust trial analysis for clustering and enter its adjusted values in the meta-analysis. Consistent condom use (dichotomous outcome) was estimated using intention-to-treat analysis and included all subjects who were randomized, regardless of baseline condom use behavior. Reduction of unprotected sexual acts (continuous outcome) was estimated through an available case analysis, and the potential impact of missing data on the results was discussed.

The meta-analysis for both dichotomous and continuous outcomes used random-effects model in the RevMan 5.3 software. This strategy accounts for potential heterogeneity following unique intervention approaches developed in diverse study settings. Statistical heterogeneity between results of different studies was examined with the $\chi^{2}$ test. A p-value for a $\chi^{2}$ test of less than 0.10 indicated heterogeneity. An alternative approach to quantify the effect of heterogeneity is assessing the inconsistency (I2) among the results of studies with $95 \%$ uncertainty intervals. A value of $0 \%$ indicates no observed heterogeneity, and a value greater than 50\% indicates substantial heterogeneity. Reporting bias was assessed by examining a funnel plot graph, which can detect small trial effects, even those resulting from publication bias.

The protocol for the first systematic review was planned to conduct subgroup analyses in order to explore possible sources of heterogeneity, but which were not performed because few studies were included. In the update, subgroup analyses were feasible for the dichotomous outcome (e.g., consistent condom use). We performed such analyses taking into account interventions that exclusively targeted (versus did not exclusively target) women living with HIV, and another considering the countries where the studies were done (North America versus Africa). 


\section{Results}

In the first comprehensive search for this review 30 , out of 3,046 citations, 35 potentially relevant studies and their full-text versions were extracted. The search in the update was performed in July 2014 and retrieved 1,721 citations. Thirty-four intervention studies were selected for full-text review in the update, including 24 articles, 6 conference proceedings, and 4 registered trials. For the sake of comprehensiveness, we reported the results of the selection process just to the period from 2010 to 2014, when 3 new studies were included in the meta-analysis. The flowchart in Figure 1 summarizes the study selection process. The quantitative syntheses jointly describe the results from studies included in the first version ( 5 studies) and in the update ( 3 studies). Likewise, the qualitative syntheses comprised 13 studies ( 5 from the first version plus 8 added in the update).

\section{Figure 1}

Screening process for systematic review update.

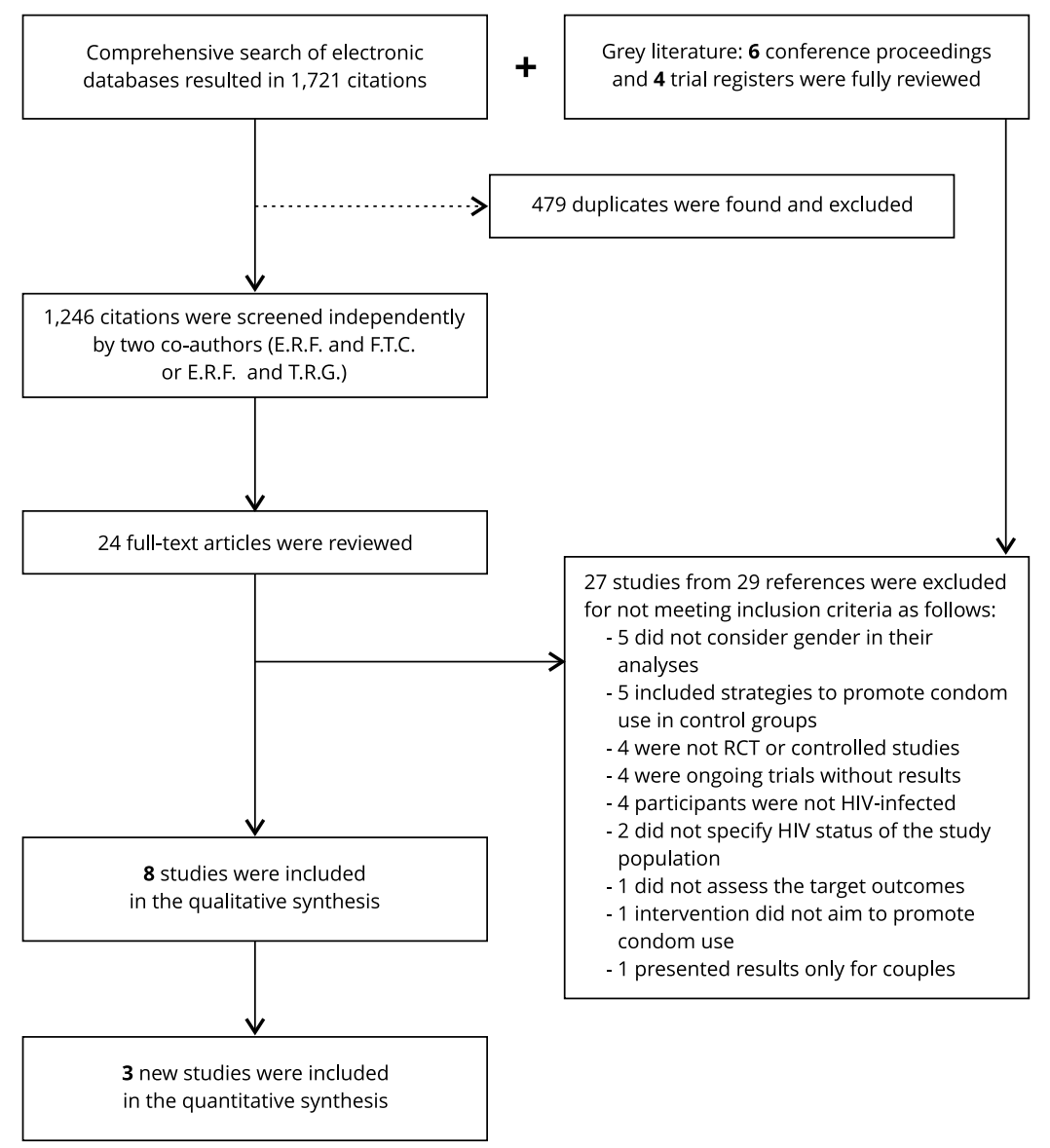

RCT: randomized clinical trials. 


\section{Included studies}

Data from 8 RCT with a total of 1,355 women living with HIV were included in the meta-analyses. Of these, 5 were conducted in the United States 29,35,36,37,38 and 3 in South Africa 39,40,41. Five interventions were developed exclusively for women living with HIV 29,37,38,40,41 and 3 targeted both women and men living with HIV 35,36,39. None targeted couples or participants' sex partners. One intervention was developed for pregnant women in sub-Saharan African communities including those living with HIV 40. All interventions followed the initiation of ART.

Even after contact with authors by e-mail, another 3 studies that met the inclusion criteria could not be included in the meta-analysis, since no further information was obtained about either the absolute number of women living with HIV engaged in safe sex or the mean and standard deviation of protected sexual acts $42,43,44$, besides another study due to lack of further information on analyses done on intervention effects by gender 45 . We identified only 1 non-randomized study 46 which provided complete data on female participants, which was not included in the meta-analysis to avoid potential confounding. We decided to include the 5 interventions in the systematic review and describe the results reported narratively by the authors. All 5 studies were developed in the United States, and 3 involved interventions targeting women living with HIV 42,43,44. Kalichman et al. 45 conducted interventions for women and men living with HIV separately, and Fisher et al. 46 included both female and male participants in the intervention or comparison groups.

Considering the 13 studies included in the systematic review, most involved group-level interventions $29,36,37,38,41,42,43,44,45$ and were delivered in settings for HIV care 29,35,38,39,42,43,44,45,46. One was home-based 40 and another 3 were developed in community settings $36,37,41$. The intervention facilitators were only health workers in 6 interventions 36,38,39,40,43,46, health workers plus peer leaders in 4 interventions $29,41,44,45$, and only peer leaders in 1 intervention 37 . One intervention was computerdelivered 35 and another failed to report this information 42.

All interventions followed standardized procedures. Principles of cognitive-behavioral theory guided almost all of the interventions, focusing on motivational interview, stress management and coping strategies, and psycho-educational techniques. One intervention 37 involved narrative strategies and social support, and 4 added components of gender and power theories 29,37,41,44. Only 6 studies explicitly mentioned that gender issues were included in the interventions 29,37,38,41,43,44. Eight interventions focused primarily on changing sexual risk behavior and secondarily included such issues as HIV status disclosure, health care, and social support 29,37,39,41,42,43,44,45. Four interventions also encompassed drug use 35,38,40,46 and another covered mental health issues 36 . Beyond sexual risk behavior, 1 intervention targeted infant growth and nutrition, breastfeeding, and medical adherence 40 , while another aimed to improve adherence to antiretroviral therapy ${ }^{38}$. Regarding total time of exposure to interventions, in 3 studies it was less than three hours 35,39,46, in 6 it ranged from 5 to 10 hours 37,40,42,43,44,45, in another 3 it ranged from 13 to 16 hours 29,38,41, and in 1 study exposure lasted 22 hours and a half 36.

Table 1 shows details on methodology, participants, interventions, and outcomes for each included study.

\section{Excluded studies}

After assessment, 27 studies were excluded: 5 did not consider gender in their outcome analyses; 5 included strategies to promote condom use in control groups; 4 were not RCT or CCT studies; 4 included non-HIV-infected participants; 2 did not determine the study population's HIV status; 1 did not assess the target outcomes; 1 intervention did not aim to promote condom use; and 1 only presented results for couples. Another 4 studies were ongoing trials 47,48,49,50 and may be eligible when the results become available.

\section{Risk of bias in included studies}

There was limited evidence of selection bias, selective reporting, and other biases across all the studies. It was not possible to clearly define the method used in random sequence generation 42,45 or the 
Table 1

Characteristics of included studies $(n=13)$ *.

\begin{tabular}{|c|c|c|c|c|c|}
\hline Study (year)/Place & $\begin{array}{l}\text { Method, time of } \\
\text { study, and follow- } \\
\text { up assessment }\end{array}$ & Population & $\begin{array}{l}\text { Interventions and } \\
\text { comparison conditions }\end{array}$ & $\begin{array}{l}\text { Outcome measures } \\
\text { (condom use } \\
\text { behavior and STIs) ** }\end{array}$ & Notes \\
\hline \multicolumn{6}{|l|}{$\begin{array}{l}\text { Studies included } \\
\text { in the meta- } \\
\text { analyses }\end{array}$} \\
\hline $\begin{array}{l}\text { Cornman et al. } 39 \\
\text { (2008)/South Africa }\end{array}$ & $\begin{array}{l}\text { Parallel RCT; October } \\
2004 \text { to August } \\
2005 \text { (recruitment); } \\
\text { 6-month follow-up. }\end{array}$ & $\begin{array}{c}152 \text { people living } \\
\text { with HIV. Mean } \\
\text { age } 34 \text { years } \\
\text { (range 18-58); } \\
\text { 43\% had finished } \\
\text { High School; 91\% } \\
\text { were Zulu; 70\% } \\
\text { were unemployed. } \\
\text { Intervention } \\
\text { group (n = 103; } \\
53 \text { women); } \\
\text { Comparison group } \\
\text { (n = } 49 ; 34 \text { women). }\end{array}$ & 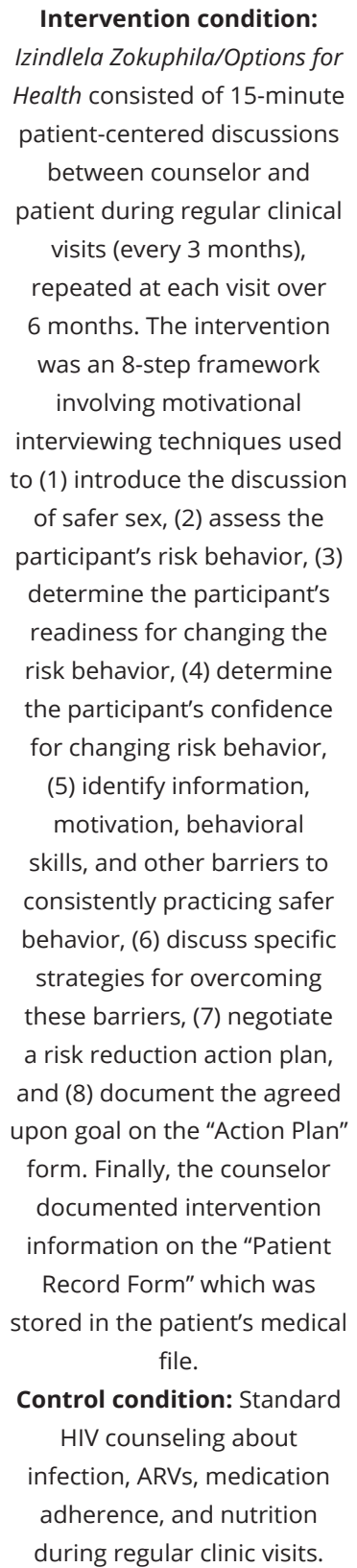 & $\begin{array}{l}\text { Self-report } \\
\text { questionnaires; } \\
\text { Total number of } \\
\text { unprotected sex } \\
\text { events (vaginal/anal } \\
\text { sexual events without } \\
\text { condoms) in previous } \\
3 \text { months; Number of } \\
\text { times condoms were } \\
\text { used for each type } \\
\text { of sex. }\end{array}$ & $\begin{array}{l}\text { Participants were } \\
\text { not tested for STIs. } \\
\text { Estimated means for } \\
\text { frequency of condom } \\
\text { use are reported. } \\
\text { On request, authors } \\
\text { provided absolute } \\
\text { numbers of female } \\
\text { participants } \\
\text { who reported } \\
\text { unprotected sexual } \\
\text { behavior at baseline } \\
\text { and 6-month } \\
\text { follow-up. }\end{array}$ \\
\hline
\end{tabular}

(continues) 
Table 1 (continued)

\begin{tabular}{|c|c|c|c|c|c|}
\hline Study (year)/Place & $\begin{array}{l}\text { Method, time of } \\
\text { study, and follow- } \\
\text { up assessment }\end{array}$ & Population & $\begin{array}{l}\text { Interventions and } \\
\text { comparison conditions }\end{array}$ & $\begin{array}{l}\text { Outcome measures } \\
\text { (condom use } \\
\text { behavior and STIs) ** }\end{array}$ & Notes \\
\hline $\begin{array}{l}\text { DeMarco \& Chan } 37 \\
\text { (2013)/Boston, USA }\end{array}$ & $\begin{array}{l}\text { Parallel RCT; Study } \\
\text { dates not reported; } \\
\text { 6-week and 6- } \\
\text { month follow-ups. }\end{array}$ & $\begin{array}{l}111 \text { low-income } \\
\text { black women } \\
\text { living with HIV } \\
\text { participants were } \\
\text { older than } 40 \text { years } \\
\text { (M = 44.6; SD = 8.5). } \\
\text { Intervention group } \\
\text { ( } \mathrm{n}=56) \text {; Control } \\
\text { group }(\mathrm{n}=55) .\end{array}$ & $\begin{array}{l}\text { Intervention condition: } \\
\text { Sistah Powah consisted of four } \\
\text { weekly 90-minute peer-led } \\
\text { group sessions focused on } \\
\text { individual writing technique } \\
\text { which allowed participants } \\
\text { to share their stories, ideas, } \\
\text { and emotions. Intervention } \\
\text { steps involved initial } \\
\text { meditation, writing process, } \\
\text { and writing sharing with the } \\
\text { group in a supportive and } \\
\text { nonjudgmental environment. } \\
\text { A clip from the film Women's } \\
\text { Voices Women's Lives was } \\
\text { used as the prompt and } \\
\text { involved four prevention } \\
\text { messages: (1) finding out } \\
\text { HIV; (2) the experience of } \\
\text { stigma; (3) being a woman } \\
\text { and negotiating safe sex; } \\
\text { and (4) surviving with a life- } \\
\text { threatening illness. } \\
\text { Control condition: } \\
\text { Four weekly } 90 \text {-minute } \\
\text { peer-led control support } \\
\text { group sessions involved } \\
\text { conversation on free topics, } \\
\text { information-sharing, and } \\
\text { discovering available health } \\
\text { services. }\end{array}$ & $\begin{array}{l}\text { Self-report } \\
\text { questionnaires; } \\
\text { Questions from MOS } \\
\text { for HIV/AIDS: “How } \\
\text { often do you usually } \\
\text { use safer sex practices } \\
\text { as a substitute for } \\
\text { unprotected sex?"; } \\
\text { "How often do you use } \\
\text { condoms when you } \\
\text { have sex?" A numeric } \\
\text { score was obtained } \\
\text { for safe sex and } \\
\text { condom use based } \\
\text { on an } 11 \text {-point scale } \\
\text { ranging from never (0) } \\
\text { to all the time (10). }\end{array}$ & $\begin{array}{l}\text { Authors provided } \\
\text { additional data (by } \\
\text { e-mail) regarding } \\
\text { absolute number of } \\
\text { women who reported } \\
\text { consistent condom } \\
\text { use at baseline } \\
\text { and each follow-up } \\
\text { assessment in control } \\
\text { and intervention } \\
\text { groups. Participants } \\
\text { were not tested for } \\
\text { STIs. }\end{array}$ \\
\hline
\end{tabular}

(continues)

allocation concealment strategy 37,42 used in three of the studies, while another two studies used quasi-experimental designs 43,46. All authors who were contacted responded with explanations for participants' dropout. Four studies did not report attrition 37,41,42,43, however, authors of 2 studies included in the meta-analysis did describe the absolute number of participants for each target outcome 37,41. Regarding loss to follow-up, the following studies found higher percentages of female participants dropping out before the last assessment, considering both control and intervention groups: Sikkema et al. 36 (41\%); Gilbert et al. 35 (28.5\%), and Saleh-Onoya et al. 41 (24.5\%). The remaining studies had $15 \%$ loss to follow-up or less.

Most studies performed intent-to-treat analysis, but 3 of the included studies 37,41,42 and 1 that was not included 43 in the meta-analysis did not perform it. It was not possible to determine whether intent-to-treat analysis was used in another study 40. Figure 2 summarizes reviewers' assessment of the studies' methodological qualities. 
Table 1 (continued)

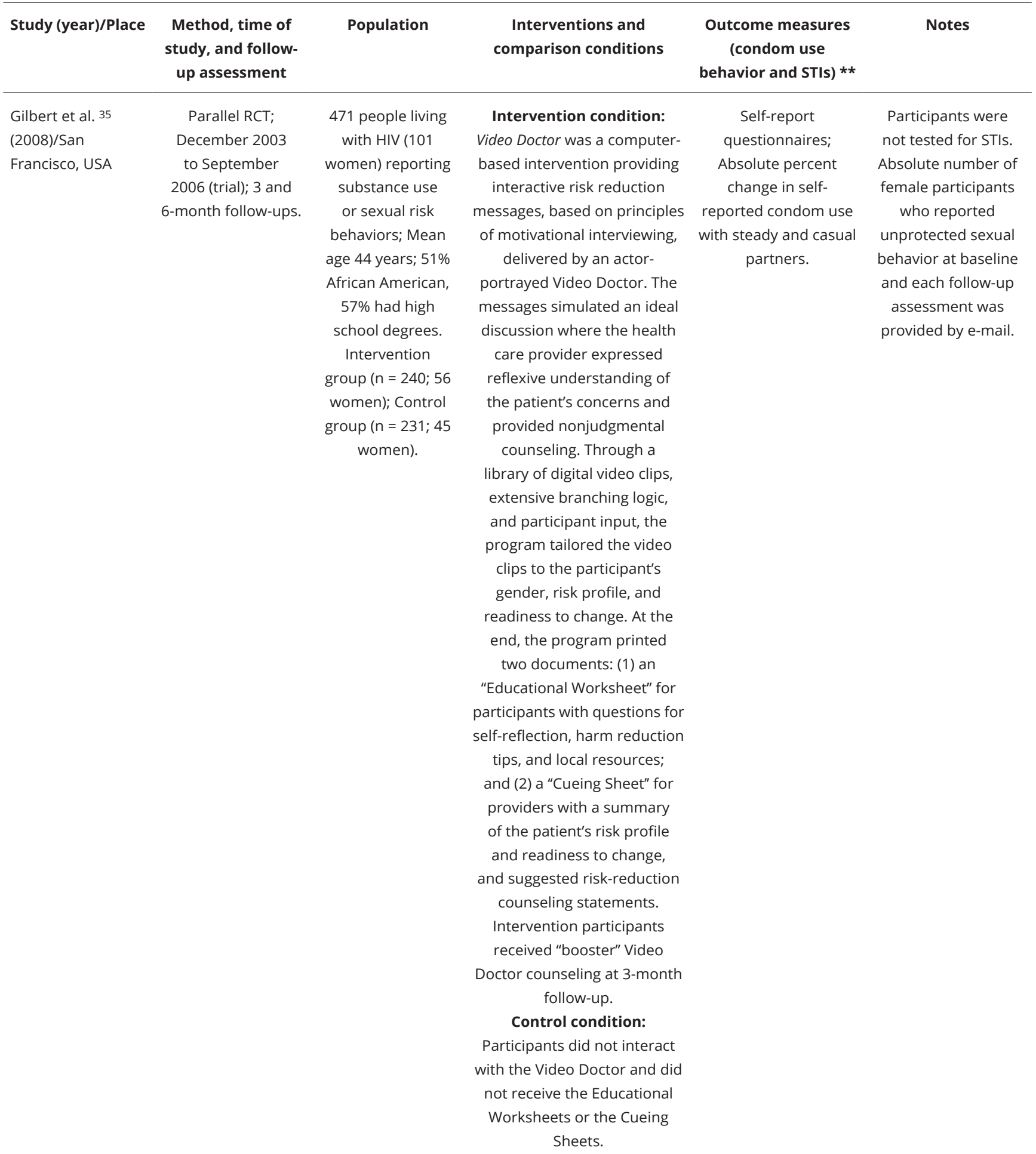

(continues) 
Table 1 (continued)

\begin{tabular}{|c|c|c|c|c|c|}
\hline Study (year)/Place & $\begin{array}{l}\text { Method, time of } \\
\text { study, and follow- } \\
\text { up assessment }\end{array}$ & Population & $\begin{array}{l}\text { Interventions and } \\
\text { comparison conditions }\end{array}$ & $\begin{array}{l}\text { Outcome measures } \\
\text { (condom use } \\
\text { behavior and STIs) ** }\end{array}$ & Notes \\
\hline $\begin{array}{l}\text { Holstad et al. } 38 \\
\text { (2011)/Atlanta, USA }\end{array}$ & $\begin{array}{l}\text { Parallel RCT; January } \\
2005 \text { to January } \\
2008 \text { (all studies); } \\
\text { 2-week, 3, 6, and } \\
\text { 9-month follow-ups. }\end{array}$ & $\begin{array}{l}203 \text { women living } \\
\text { with HIV. Mean age } \\
43.5 \text { years (SD = 9.2; } \\
\text { range 18-58); 93.1\% } \\
\text { African American; } \\
84.2 \% \text { unemployed } \\
\text { (84.2\%). } \\
\text { Intervention group } \\
\text { ( } n=101) \text {, Control } \\
\text { group }(n=102) .\end{array}$ & $\begin{array}{l}\text { Intervention condition: } \\
\text { The Keeping Healthy and } \\
\text { Active with Risk Reduction } \\
\text { and Medication Adherence } \\
\text { intervention (KHARMA) } \\
\text { consisted of eight 1.5-2-hour } \\
\text { group sessions focused on } \\
\text { empowering women for } \\
\text { decision-making related to } \\
\text { both ART adherence and risk } \\
\text { reduction behaviors (e.g., } \\
\text { sexual practices and drug } \\
\text { use) through motivational } \\
\text { interviewing. Each session } \\
\text { included a group discussion, } \\
\text { and participants also received } \\
\text { a purse- size inspirational } \\
\text { calendar, motivational journal, } \\
\text { motivational adherence video, } \\
\text { male and female condoms, } \\
\text { dental dams, and lubricants. } \\
\text { Control Condition: Consisted } \\
\text { of eight 1.5-2-hour group } \\
\text { sessions based on health } \\
\text { education techniques } \\
\text { of lecture/discussion/ } \\
\text { educational games and } \\
\text { focused on nutrition, } \\
\text { exercise, stress recognition, } \\
\text { and women's health issues } \\
\text { tailored to the HIV-positive } \\
\text { woman. Participants received } \\
\text { a manual containing content } \\
\text { and supplementary materials } \\
\text { for each session. }\end{array}$ & $\begin{array}{c}\text { Self-report } \\
\text { questionnaires. } \\
\text { Consistent condom } \\
\text { use during vaginal/ } \\
\text { oral/anal sex (e.g. } \\
\text { always vs. all else) } \\
\text { in the previous } 3 \\
\text { months. }\end{array}$ & $\begin{array}{l}\text { Participants were } \\
\text { not tested for STIs. } \\
\text { Absolute number } \\
\text { of participants who } \\
\text { reported consistent } \\
\text { condom use at } \\
\text { baseline and each } \\
\text { follow-up assessment } \\
\text { for both group was } \\
\text { provided by e-mail. }\end{array}$ \\
\hline
\end{tabular}

(continues)

\section{Quality of the evidence}

We performed a GRADE evaluation of the quality of evidence for all interventions included in this meta-analysis 32,33 . The GRADE system provided a structured approach to assess the quality of evidence across studies for each outcome included in the review according to risk of bias, publication bias, inconsistency, indirectness, and imprecision 32,33. This classification indicated low quality of evidence for consistent condom use and very low quality of evidence for reduction in unprotected sexual acts. We downgraded the quality of evidence twice for both outcomes, based on the wide confidence intervals, indicating imprecision, and because results from different intervention protocols, with differences in duration, providers, and delivery cannot be generalized to diverse populations of women living with HIV (indirectness). We also downgraded the quality of evidence for the reduction 
Table 1 (continued)

\begin{tabular}{|c|c|c|c|c|c|}
\hline Study (year)/Place & $\begin{array}{l}\text { Method, time of } \\
\text { study, and follow- } \\
\text { up assessment }\end{array}$ & Population & $\begin{array}{l}\text { Interventions and } \\
\text { comparison conditions }\end{array}$ & $\begin{array}{c}\text { Outcome measures } \\
\text { (condom use } \\
\text { behavior and STIs) ** }\end{array}$ & Notes \\
\hline $\begin{array}{l}\text { Le Roux et al. } 40 \\
\text { (2013)/Cape Town, } \\
\text { South Africa }\end{array}$ & $\begin{array}{l}\text { Cluster RCT; May } \\
2009 \text { to September } \\
2010 \text { (recruitment); } \\
\text { 6-month follow-ups. }\end{array}$ & $\begin{array}{l}\text { 1,238 pregnant } \\
\text { women from } 24 \\
\text { neighborhoods. } \\
\text { Mean age } 26 \text { years } \\
\text { (SD = 5.5); mean } \\
\text { education } 10 \text { years } \\
\text { (SD = 1.8); } 19 \% \\
\text { never employed. } \\
\text { Intervention } \\
\text { communities ( } 20 \\
\text { neighborhoods; } \\
\text { n = 644; } 185 \\
\text { HIV+). Control } \\
\text { communities ( } 20 \\
\text { neighborhoods; } \\
\text { n = 594; } 169 \text { HIV+). }\end{array}$ & $\begin{array}{l}\text { Intervention condition: The } \\
\text { Philani Intervention Program } \\
\text { (PIP) involved antenatal and } \\
\text { postnatal home visits by } \\
\text { community health workers. } \\
\text { Facilitators provided antenatal } \\
\text { messages on good nutrition, } \\
\text { breastfeeding, antenatal clinic } \\
\text { attendance and danger signs, } \\
\text { HIV testing, PMTCT tasks and } \\
\text { partner prevention strategies } \\
\text { and alcohol cessation. } \\
\text { Postnatal messages involved } \\
\text { breastfeeding and infant } \\
\text { growth monitoring, medical } \\
\text { adherence, infant bonding, } \\
\text { and assuring the child grant. } \\
\text { On average, health workers } \\
\text { made six antenatal visits and } \\
\text { five postnatal visits, which } \\
\text { lasted } 31 \text { minutes. } \\
\text { Control condition: The } \\
\text { standard care condition } \\
\text { consisted of access to } \\
\text { routines during pregnancy, } \\
\text { delivery, and for the infant. } \\
\text { including rapid HIV testing, }\end{array}$ & $\begin{array}{c}\text { Self-report } \\
\text { questionnaires; } \\
\text { Consistent condom } \\
\text { use. }\end{array}$ & $\begin{array}{l}\text { A direct estimate } \\
\text { of consistent } \\
\text { condom use among } \\
\text { participants living } \\
\text { with HIV accounting } \\
\text { for the cluster design } \\
\text { was obtained with } \\
\text { statistical support. } \\
\text { Adjusted data were } \\
\text { used in the meta- } \\
\text { analysis considering } \\
\text { the ICC reported } \\
\text { by authors in the } \\
\text { formative study } 40 . \\
\text { Baseline data on } \\
\text { outcome were not } \\
\text { available. }\end{array}$ \\
\hline
\end{tabular}

(continues)

in unprotected sexual relations, considering the inconsistency criteria, since it was not possible to conduct subgroup analyses to explore the sources of the moderate heterogeneity. The summary of findings can be accessed in Table 1 of the Supplementary Material: https://www.dropbox.com/s/ tjhjhozyn8h235o/Supplementary\%20Material\%20reviewed.pdf?dl=0.

We specifically considered that the imprecision could also relate to the lack of sample size calculation in $336,39,41$ out of 8 included studies $35,38,40$ and to the fact that the overall sample size across studies for both outcomes (in each follow-up assessment) appears too small to estimate a relevant public health impact from behavioral interventions on condom use. Based on the results of the metaanalysis, the optimal information size for the dichotomous outcome - consistent condom use - would require 4,356 participants in each intervention arm (e.g., P1 expected proportion in the control group $555 / 1,103=0.50$; P2 expected proportion in the intervention group 612/1, $162=0.53$; lowest $\mathrm{p}=0.75$; difference between P1 and P2 = 0.03; alpha and beta of 0.05 and 0.20, respectively 51). Moreover, three of the studies included in the meta-analysis targeted both women and men, having lower percentages of female participants. 
Table 1 (continued)

\begin{tabular}{|c|c|c|c|c|c|}
\hline Study (year)/Place & $\begin{array}{l}\text { Method, time of } \\
\text { study, and follow- } \\
\text { up assessment }\end{array}$ & Population & $\begin{array}{l}\text { Interventions and } \\
\text { comparison conditions }\end{array}$ & $\begin{array}{l}\text { Outcome measures } \\
\text { (condom use } \\
\text { behavior and STIs) ** }\end{array}$ & Notes \\
\hline $\begin{array}{l}\text { Saleh-Onoya et al. } 41 \\
\text { (2009)/Western Cape } \\
\text { Province, South Africa }\end{array}$ & $\begin{array}{l}\text { Parallel RCT; June } \\
\text { to August } 2003 \\
\text { (recruitment). } \\
\text { 3-month follow-up. }\end{array}$ & $\begin{array}{l}102 \text { women living } \\
\text { with HIV. Mean } \\
\text { age } 29 \text { years } \\
\text { (range 18-50), } \\
\text { isiXhosa speaking. } \\
\text { Intervention group } \\
\text { ( } \mathrm{n}=53) \text {, Control } \\
\text { group }(\mathrm{n}=49 \text { ). }\end{array}$ & $\begin{array}{l}\text { Intervention condition: } \\
\text { Consisted of four weekly } \\
\text { 4-hour sessions of sexual risk } \\
\text { reduction and coping training } \\
\text { focused on (1) enhancing } \\
\text { ethnic and gender pride and } \\
\text { self-esteem, (2) communication } \\
\text { styles, reinforcing assertive } \\
\text { communication skills, (3) } \\
\text { HIV and STI knowledge, and } \\
\text { highlighted personal HIV risk } \\
\text { associated with unsafe sexual } \\
\text { behavior, negotiating condom } \\
\text { use with sex partners, learning } \\
\text { skills for correct condom } \\
\text { use, and (4) differentiated } \\
\text { healthy and unhealthy } \\
\text { relationships, and methods for } \\
\text { safely resolving relationship } \\
\text { problems. Most Intervention } \\
\text { activities were adopted from } \\
\text { the original WiLLOW program } \\
\text { which was culturally adapted } \\
\text { through previous focus group } \\
\text { discussions. } \\
\text { Control condition: Consisted } \\
\text { of one 4-hour session focused } \\
\text { on reiterating motivational } \\
\text { messages about developing a } \\
\text { positive outlook on life despite } \\
\text { the challenges of living with } \\
\text { HIV. }\end{array}$ & $\begin{array}{c}\text { Self-report } \\
\text { questionnaires, vaginal } \\
\text { swabs. STI prevalence } \\
\text { and incidence (CT, NG, } \\
\text { TV, and BV). Condom } \\
\text { use in the last sexual } \\
\text { intercourse, and in the } \\
\text { previous month. }\end{array}$ & None. \\
\hline
\end{tabular}

(continues)

\section{Assessment of publication bias}

A meta-analysis can be vulnerable to publication bias if studies with less favorable results are not found. A useful test for publication bias is based on the funnel plot, which compares intervention effects estimated from individual studies against a measure of study size. In the absence of bias, the plot resembles a symmetrical inverted funnel 52. However, the test is underpowered to distinguish chance from real asymmetry when less than 10 studies are included in the meta-analysis 31 , which was the case in this review. Even so, in order to explore evidence of publication bias, we performed funnel plots for both outcomes. For the dichotomous outcome, the funnel plot was quite symmetrical, while in the continuous outcome, which includes fewer studies, plot asymmetry could be observed (see Figures 1 and 2 in the Supplementary Material: https://www.dropbox.com/s/o3nca5vco530exk/ Supplementary\%20Material.docx?dl=0). Considering the small number of studies included in both meta-analyses, we can hypothesize that asymmetry may be also related to true heterogeneity among studies with different sizes rather than indicating publication bias, since there were differences in the intensity of the interventions as well as among HIV+ women who lived in highly diverse contexts in terms of social and individual vulnerability. 
Table 1 (continued)

\begin{tabular}{|c|c|c|c|c|c|}
\hline Study (year)/Place & $\begin{array}{l}\text { Method, time of } \\
\text { study, and follow- } \\
\text { up assessment }\end{array}$ & Population & $\begin{array}{l}\text { Interventions and } \\
\text { comparison conditions }\end{array}$ & $\begin{array}{l}\text { Outcome measures } \\
\text { (condom use } \\
\text { behavior and STIs) ** }\end{array}$ & Notes \\
\hline $\begin{array}{l}\text { Sikkema et al. } 36 \\
\text { (2008)/New York, } \\
\text { USA }\end{array}$ & $\begin{array}{l}\text { Parallel RCT; March } \\
2002 \text { to January } \\
2004 \text { (recruitment). } \\
3,6 \text { and } 12 \text {-month } \\
\text { follow-ups. }\end{array}$ & $\begin{array}{l}247 \text { people living } \\
\text { with HIV with history } \\
\text { of sexual trauma. } \\
\text { Mean age } 42.3 \\
\text { years ( } \mathrm{SD}=6.8 \text { ) and } \\
\text { mean education } \\
\text { 12.2 years ( } \mathrm{SD}=2.4) . \\
\text { Intervention group } \\
\text { ( } \mathrm{n}=124 ; 62 \text { women), } \\
\text { Control group }(\mathrm{n}= \\
123 ; 67 \text { women). }\end{array}$ & $\begin{array}{l}\text { Intervention condition: } \\
\text { The intervention consisted of } \\
15 \text { weekly } 90 \text {-minute group } \\
\text { sessions which integrated the } \\
\text { cognitive theory of stress and } \\
\text { coping and effective cognitive- } \\
\text { behavioral strategies, } \\
\text { focused on stressors related } \\
\text { to sexual abuse and HIV. } \\
\text { Therapeutic activities included } \\
\text { identification of individual } \\
\text { triggers, selection of } \\
\text { attainable goals, skill-building } \\
\text { exercises, and exposure. } \\
\text { Risk-reduction skills were } \\
\text { addressed in the context } \\
\text { of elements necessary for } \\
\text { healthy relationships. } \\
\text { Control condition: Consisted } \\
\text { of } 15 \text { weekly } 90 \text {-minute } \\
\text { standard therapeutic support } \\
\text { groups aimed to address } \\
\text { issues of HIV and trauma. } \\
\text { Despite the open format, } \\
\text { the group content had a } \\
\text { predominant focus on the } \\
\text { connections between sexual } \\
\text { abuse, HIV/AIDS, current } \\
\text { relationships, and life events. }\end{array}$ & $\begin{array}{c}\text { Self-report } \\
\text { questionnaires. } \\
\text { Number of times they } \\
\text { had engaged in anal/ } \\
\text { vaginal intercourse } \\
\text { in the previous } 4 \\
\text { months. Condom use } \\
\text { and partner serostatus } \\
\text { were assessed } \\
\text { specific to intercourse } \\
\text { occasions. }\end{array}$ & $\begin{array}{l}\text { Absolute number of } \\
\text { female participants } \\
\text { who reported } \\
\text { unprotected sexual } \\
\text { behavior as well } \\
\text { as proportions of } \\
\text { safe sexual acts at } \\
\text { baseline and each } \\
\text { follow-up assessment } \\
\text { were provided by } \\
\text { e-mail. Participants } \\
\text { were not tested } \\
\text { for STIs. }\end{array}$ \\
\hline
\end{tabular}

(continues)

\section{Effects of interventions}

In this updated review, we conducted meta-analyses for two different outcomes: consistent condom use and reduction in unprotected sexual intercourse, respectively. A meta-analysis of the 8 studies did not demonstrate an effect of behavioral interventions on consistent condom use among women living with HIV when compared to standard care or minimal HIV support interventions. No intervention effects on consistent condom use were noted at the 3-month follow-up (RR = 0.92; 95\%CI: 0.73, 1.16; $\mathrm{p}=0.48)$, 6-month follow-up $(\mathrm{RR}=1.13$; 95\%CI: 0.96, 1.34; $\mathrm{p}=0.15)$, and 12-month follow-up $(\mathrm{RR}=$ 0.91; 95\%CI: 0.77, 1.08; $\mathrm{p}=0.30)$ or the overall effect $(\mathrm{RR}=1.02 ; 95 \% \mathrm{CI}: 0.92,1.12 ; \mathrm{p}=0.74)$.

The overall result for consistent condom use showed evidence of moderate heterogeneity, indicating some inconsistency across study results $\left(\tau^{2}=0.08 ; \chi^{2}=19.92, \mathrm{df}=12, \mathrm{p}=0.07, \mathrm{I}^{2}=40 \%\right)$. As shown in Figure 3, the higher heterogeneity for consistent condom use was found at the 6 month follow-up, probably related to positive results found by one study ${ }^{37}$. Subgroup analyses could not distinguish statistically significant differences in the intervention effect considering interventions that exclusively targeted (versus did not exclusively target) women living with HIV, or between the countries where they were conducted, i.e., in North America compared to Africa (see Figures 3, 4 and 5 in the Supplementary Material: https://www.dropbox.com/s/tjhjhozyn8h235o/Supplementary\%20Mate rial\%20reviewed.pdf?dl=0). 
Table 1 (continued)

\begin{tabular}{|c|c|c|c|c|c|}
\hline Study (year)/Place & $\begin{array}{l}\text { Method, time of } \\
\text { study, and follow- } \\
\text { up assessment }\end{array}$ & Population & $\begin{array}{l}\text { Interventions and } \\
\text { comparison conditions }\end{array}$ & $\begin{array}{l}\text { Outcome measures } \\
\quad \text { (condom use } \\
\text { behavior and STIs) ** }\end{array}$ & Notes \\
\hline $\begin{array}{l}\text { Wingood et al. } 29 \\
\text { (2004)/Alabama } \\
\text { and Georgia, USA }\end{array}$ & $\begin{array}{c}\text { Parallel RCT; } \\
\text { September } 1997 \\
\text { to December } 2000 \\
\text { (recruitment). } 6 \text { and } \\
\text { 12-month follow- } \\
\text { ups. }\end{array}$ & $\begin{array}{l}366 \text { women living } \\
\text { with HIV } \\
\text { Mean age } 34.7 \\
\text { years (SD = 7.6); } \\
\text { 84\% black; 70\% } \\
\text { unemployed (70\%); } \\
\text { 63.7\% had high } \\
\text { school degrees. } \\
\text { Intervention group } \\
\text { (n = 190), Control } \\
\text { group ( } \mathrm{n}=176) \text {. }\end{array}$ & $\begin{array}{l}\text { Intervention condition: } \\
\text { The WiLLOW intervention } \\
\text { consisted of four weekly } \\
\text { 4-hour group sessions based } \\
\text { on the social cognitive theory } \\
\text { and the theory of gender and } \\
\text { power. Session } 1 \text { emphasized } \\
\text { gender pride and assisted } \\
\text { women in identifying their } \\
\text { supportive network members. } \\
\text { Session } 2 \text { discussed ways of } \\
\text { maintaining and enlarging } \\
\text { supportive network members, } \\
\text { and disengaging from } \\
\text { non-supportive network } \\
\text { members. Session } 3 \\
\text { enhanced awareness of HIV } \\
\text { transmission risk behaviors } \\
\text { and taught participants } \\
\text { communication skills for } \\
\text { negotiating safer sex and } \\
\text { reinforced proper condom } \\
\text { use skills. Session } 4 \text { taught } \\
\text { women to distinguish } \\
\text { between healthy and } \\
\text { unhealthy relationships, } \\
\text { discussed the impact of } \\
\text { abusive partners on safer } \\
\text { sex, and informed about local } \\
\text { shelters for women in abusive } \\
\text { relationships. } \\
\text { control condition: Consisted } \\
\text { interactive group sessions } \\
\text { addressing medication } \\
\text { adherence, nutrition, and } \\
\text { provider interaction skills. }\end{array}$ & $\begin{array}{c}\text { Self-report } \\
\text { questionnaires and } \\
\text { vaginal swabs. STI } \\
\text { prevalence and } \\
\text { incidence (CT, NG, TV, } \\
\text { and BV). Frequency } \\
\text { of unprotected } \\
\text { vaginal intercourse } \\
\text { in the } 30 \text { days and } \\
6 \text { months preceding } \\
\text { assessments. }\end{array}$ & None. \\
\hline
\end{tabular}

(continues)

A combination of particular characteristics of DeMarco \& Chan's study 37 deserves to be mentioned, since it could be related to the positive results found in the meta-analysis. The Sistah Powah Structured Writing Intervention targeted aging, low-income, black women living with HIV, a group of women highly neglected by secondary prevention efforts because pregnancy is less likely and who face strong social vulnerability and stigma 53. The intervention was conducted in small groups and was the only one that was exclusively peer-led, involved culturally relevant narrative techniques, and helped to build a social support network in a community setting. Considering the population and the intervention's characteristics jointly, its success in promoting consistent condom use could be linked to a more effective approach to empower women living with HIV, stimulating their 
Table 1 (continued)

\begin{tabular}{|c|c|c|c|c|c|}
\hline Study (year)/Place & $\begin{array}{l}\text { Method, time of } \\
\text { study, and follow- } \\
\text { up assessment }\end{array}$ & Population & $\begin{array}{l}\text { Interventions and } \\
\text { comparison conditions }\end{array}$ & $\begin{array}{l}\text { Outcome measures } \\
\text { (condom use } \\
\text { behavior and STIs) ** }\end{array}$ & Notes \\
\hline \multicolumn{6}{|l|}{$\begin{array}{l}\text { Studies included } \\
\text { in the systematic } \\
\text { review }\end{array}$} \\
\hline $\begin{array}{l}\text { Echenique et al. } 42 \\
\text { (2013)/Miami, USA }\end{array}$ & $\begin{array}{l}\text { Parallel RCT; } 2004 \text { to } \\
2006 \text { (recruitment); } \\
6 \text { and } 12 \text {-month } \\
\text { follow-ups. }\end{array}$ & $\begin{array}{l}106 \text { women living } \\
\text { with HIV older } \\
\text { than } 45 \text { years; } 83 \% \\
\text { African American } \\
\text { and } 45.3 \% \text { had High } \\
\text { School degrees; } \\
\text { Intervention group } \\
\text { (n=65), Control } \\
\text { group ( } n=41) \text {. }\end{array}$ & $\begin{array}{l}\text { Intervention conditions: } \\
\text { Consisted of four weekly } \\
\text { 2-hour psycho-educational } \\
\text { group sessions designed for } \\
\text { older HIV positive adults. In } \\
\text { the first session, educational } \\
\text { information on HIV was } \\
\text { provided. Subsequent } \\
\text { sessions focused on the } \\
\text { impact of HIV on sexual } \\
\text { behaviors, practicing } \\
\text { harm reduction, assertive } \\
\text { communication, and condom } \\
\text { negotiation skill building. } \\
\text { The last session was used to } \\
\text { review lessons and discuss } \\
\text { safer sex techniques and } \\
\text { strategies to maintain safe } \\
\text { sexual behaviors. } \\
\text { Control condition: Control } \\
\text { group participants received } \\
\text { care as usual and an } \\
\text { educational brochure. }\end{array}$ & $\begin{array}{c}\text { Self-report } \\
\text { questionnaires. } \\
\text { Number of vaginal/ } \\
\text { anal sexual acts } \\
\text { with HIV-infected, } \\
\text { negative, or unknown } \\
\text { serostatus partners. } \\
\text { Number of sexual acts } \\
\text { using condoms in the } \\
\text { previous } 6 \text { months. } \\
\text { Inconsistent condom } \\
\text { use was defined as not } \\
\text { having used condoms } \\
\text { at least once during } \\
\text { this time. }\end{array}$ & $\begin{array}{l}\text { Several attempts } \\
\text { were made to obtain } \\
\text { further data from } \\
\text { authors for inclusion } \\
\text { in meta-analysis } \\
\text { and we received no } \\
\text { answer. }\end{array}$ \\
\hline
\end{tabular}

(continues)

autonomy and the adoption of adapted strategies to deal with HIV according to gender and in socially challenging settings.

As shown in Figure 4, the meta-analysis for reducing unprotected sexual intercourse (e.g., increased condom use - continuous outcome) showed no significant effects of the behavioral interventions when compared to standard care or minimal HIV support interventions at 6-month $(\mathrm{MD}=-1.80 ; 95 \% \mathrm{CI}:-4.21,0.62 ; \mathrm{p}=0.14)$ and 12 -month follow-up $(\mathrm{MD}=-1.39 ; 95 \% \mathrm{CI}:-2.29,0.21$; $\mathrm{p}=0.09)$. However, significant heterogeneity was detected $\left(\tau^{2}=1.19, \chi^{2}=9.37, \mathrm{df}=4, \mathrm{p}=0.05, \mathrm{I}^{2}=\right.$ $57 \%)$, probably reflecting the diversity of studies included in the 6-month follow-up as well as the high imprecision observed in 1 study 36 . We were unable to further explore heterogeneity with subgroup analyses due to the small number of studies included for this outcome.

Considering the statistical analyses conducted individually by the authors of the studies included in the meta-analyses, all but 1 found positive results for increased condom use 41 . Eight studies considered a combined number of sexual events in which frequency rather than consistency of condom use was the primary outcome $29,36,39,42,43,44,45,46$. Another study originally used a composite safer sex score 37 . Three other articles did not originally present data on intervention results by gender, even reporting that gender analyses were done and that no significant differences were found 35,36,39.

The current review also aimed to assess the effect of behavioral interventions on STI incidence, but only 2 studies 29,41 assessed this outcome. The studies had different timing of follow-up assessments and 1 one ${ }^{29}$ presented adequate data to be grouped by results related to STI. One study found 
Table 1 (continued)

\begin{tabular}{|c|c|c|c|c|c|}
\hline Study (year)/Place & $\begin{array}{l}\text { Method, time of } \\
\text { study, and follow- } \\
\text { up assessment }\end{array}$ & Population & $\begin{array}{l}\text { Interventions and } \\
\text { comparison conditions }\end{array}$ & $\begin{array}{l}\text { Outcome measures } \\
\text { (condom use } \\
\text { behavior and STIs) ** }\end{array}$ & Notes \\
\hline $\begin{array}{l}\text { Fisher et al. } 46 \\
\text { (2006)/Connecticut, } \\
\text { USA }\end{array}$ & $\begin{array}{l}\text { CCT; October } 2000 \\
\text { to August } 2003 \\
\text { (recruitment); } 6, \\
12 \text { and } 18 \text {-month } \\
\text { follow-ups. }\end{array}$ & $\begin{array}{l}497 \text { people living } \\
\text { with HIV (209 } \\
\text { women). Mean age } \\
43 \text { years (range: } \\
22-70 \text { years); 38\% } \\
\text { African American; } \\
\text { 35\% Hispanic; 36\% } \\
\text { had high school } \\
\text { degrees; } 69 \% \text { low } \\
\text { family incomes. } \\
\text { Intervention group } \\
\text { ( } n=252 ; 113 \\
\text { women), Control } \\
\text { group ( } n=245 ; 95 \\
\text { women). }\end{array}$ & $\begin{array}{l}\text { Intervention condition: The } \\
\text { Options/Opciones Project HIV } \\
\text { Risk Reduction intervention } \\
\text { consisted of } 5 \text { to 10-minute } \\
\text { patient-centered discussions } \\
\text { between clinician and patient } \\
\text { during routine clinical } \\
\text { visits and repeated at each } \\
\text { visit for approximately } 18 \\
\text { months. It was based on } \\
\text { the information-motivation- } \\
\text { behavioral skills model that } \\
\text { uses motivational interviewing } \\
\text { techniques. Clinicians } \\
\text { evaluated patients' sexual and } \\
\text { injection drug use behaviors } \\
\text { and their stage of change in } \\
\text { risky behaviors. Clinician and } \\
\text { patient developed an action } \\
\text { plan and patient received a } \\
\text { home task summarizing goals } \\
\text { to being reached before the } \\
\text { next visit. } \\
\text { Control condition: Consisted } \\
\text { of regular clinical visits. }\end{array}$ & $\begin{array}{c}\text { Self-report } \\
\text { questionnaires. } \\
\text { Total number of } \\
\text { unprotected vaginal/ } \\
\text { anal sexual events } \\
\text { and unprotected } \\
\text { insertive oral sexual } \\
\text { events, occurrence of } \\
\text { unprotected vaginal/ } \\
\text { anal sexual events } \\
\text { in the previous } 3 \\
\text { months. }\end{array}$ & $\begin{array}{l}\text { Participants were } \\
\text { not tested for STIs } \\
\text { and no sample } \\
\text { size calculation } \\
\text { was performed } \\
\text { (information provided } \\
\text { by e-mail). }\end{array}$ \\
\hline
\end{tabular}

(continues)

significantly higher incidence of Chlamydia trachomatis ( $\mathrm{OR}=0.21 ; 95 \% \mathrm{CI}: 0.07,0.59 ; \mathrm{p}<0.05$ ), Neisseria gonorrhoeae $(\mathrm{OR}=0.10 ; 95 \% \mathrm{CI}: 0.02,0.49 ; \mathrm{p}<0.05)$, and Trichomona vaginalis $(\mathrm{OR}=0.06 ; 95 \% \mathrm{CI}: 0.01$, $0.46 ; \mathrm{p}<0.05)$ in the control group than in the intervention at 3 months follow-up 41 . No significant difference was found for incidence of bacterial vaginosis. Wingood et al. 29 reported that participants in the intervention group were not significantly less likely to have a Trichomonas infection any followup assessment but were significantly less likely to have an bacterial STI (Chlamydia or gonorrhea) at the 12-month follow-up (OR $=0.10 ; 95 \%$ CI: $0.01,0.70 ; \mathrm{p}=0.023)$ and over the entire 12 months $(\mathrm{OR}=0.20 ; 95 \% \mathrm{CI}: 0.01,0.06 ; \mathrm{p}=0.006)$. These findings indicate that behavioral interventions could be a promising strategy to reduce STI incidence even if it cannot be confirmed through meta-analysis.

Another 5 studies were included in this systematic review but did not provide sufficient data to combine their results, and we present them in a narrative review as follows. One non-randomized trial of an intervention delivered jointly for women and men living with HIV included $45 \%$ of female participants in the intervention group and $39 \%$ in the comparison 46 . People living with HIV in the intervention group showed a significant reduction $(b=20.51 ; \mathrm{SE}=0.23, \mathrm{p}<0.05)$ in unprotected vaginal and anal intercourse and insertive oral sex over a follow-up of 18 months, while these behaviors increased among participants in the comparison $\operatorname{arm}(\mathrm{b}=0.51 ; \mathrm{SE}=0.19 ; \mathrm{p}=0.01)$. Interventions' effects remained significant when these analyses were performed separately by gender, and the effect was higher in men $(\mathrm{p}=0.002)$ than in women $(\mathrm{p}=0.04)$. In a more conservative measure (unprotected vaginal and anal sex only), authors found a trend toward a reduction in unprotected sex in the intervention group over time $(b=20.42 ; S E=0.25 ; p=0.09)$, and a significant increase among standard-of- 
Table 1 (continued)

\begin{tabular}{|c|c|c|c|c|c|}
\hline Study (year)/Place & $\begin{array}{l}\text { Method, time of } \\
\text { study, and follow- } \\
\text { up assessment }\end{array}$ & Population & $\begin{array}{l}\text { Interventions and } \\
\text { comparison conditions }\end{array}$ & $\begin{array}{c}\text { Outcome measures } \\
\text { (condom use behavior } \\
\text { and STIs) ** }\end{array}$ & Notes \\
\hline $\begin{array}{l}\text { Jones et al. } 43 \\
\text { (2001)/Miami, New } \\
\text { York and New } \\
\text { Jersey, USA }\end{array}$ & $\begin{array}{c}\text { CCT; mid-1998 } \\
\text { (recruitment } \\
\text { started); } 3 \text { and } \\
\text { 9-month follow-ups. }\end{array}$ & $\begin{array}{l}178 \text { women living } \\
\text { with HIV. Mean } \\
\text { age } 36 \text { years; } 81 \% \\
\text { employed; } 52 \% \\
\text { African American; } \\
\text { 68\% had completed } \\
\text { 12th grade. } \\
\text { Intervention group } \\
\text { (n = 89), Control } \\
\text { group ( } \mathrm{n}=89 \text { ). }\end{array}$ & $\begin{array}{l}\text { Intervention condition: } \\
\text { The Sexual Barrier } \\
\text { intervention comprised } \\
\text { three monthly 120-minute } \\
\text { sessions and provision } \\
\text { of condoms and vaginal } \\
\text { products (N-9 spermicides). } \\
\text { Sessions targeted HIV/STD } \\
\text { transmission, hierarchical } \\
\text { counseling, and skills } \\
\text { training to use condoms } \\
\text { and spermicide. Written } \\
\text { handouts, videos and hand- } \\
\text { on experiences were used to } \\
\text { discuss information. Videos } \\
\text { were developed specifically } \\
\text { for women living with HIV and } \\
\text { illustrated correct methods } \\
\text { of barrier use, as well as } \\
\text { common questions and } \\
\text { doubts. } \\
\text { Control condition: } \\
\text { Participants attended three } \\
\text { monthly discussion sessions } \\
\text { focusing on a brief stress } \\
\text { management educational } \\
\text { video, followed by an } \\
\text { entertaining film. }\end{array}$ & $\begin{array}{c}\text { Self-report } \\
\text { questionnaires. An } \\
\text { adapted 60-item } \\
\text { scale asked frequency } \\
\text { of sexual behavior, } \\
\text { number of partners, } \\
\text { and condom use during } \\
\text { the previous three } \\
\text { months with primary } \\
\text { and non-primary } \\
\text { partners. }\end{array}$ & $\begin{array}{l}\text { Authors were } \\
\text { contacted and did } \\
\text { not have available } \\
\text { data on absolute } \\
\text { number of female } \\
\text { participants who } \\
\text { reported unprotected } \\
\text { sexual intercourse } \\
\text { at baseline and each } \\
\text { follow-up assessment } \\
\text { in the two groups. } \\
\text { Participants were } \\
\text { not tested for STIs } \\
\text { during follow-up } \\
\text { assessments and } \\
\text { authors did not } \\
\text { perform a sample } \\
\text { size calculation } \\
\text { (information provided } \\
\text { by e-mail). }\end{array}$ \\
\hline
\end{tabular}

(continues)

care control participants $(\mathrm{b}=0.61 ; \mathrm{SE}=0.21 ; \mathrm{p}<0.01)$. Similar results were found for both outcomes (broader and conservative) when considering only sexual acts with HIV-negative partners or those with unknown HIV status.

Another RCT 45 included 60 women living with HIV (32\%) in the intervention arm and 38 (26\%) in the comparison arm. Since the intervention content was tailored to gender, the latter was controlled throughout the analysis, although the results were not presented separately for women and men. The results did not suggest differences between intervention and control groups for number of sexual partners reported at 3 or 6 months follow-up or for rates of unprotected intercourse at the 3-month follow-up. However, there were significant differences between conditions for rates of unprotected sexual acts $(\mathrm{OR}=2.2$; 95\% CI: $0.23,4.17)$ and condom use rate at the 6 -month follow-up $(\mathrm{OR}=-17.1$; 95\%CI: $-27.94,-6.26)$ regardless of the partner's HIV status (OR and 95\%CI calculated based on the reported means and standard deviations). Considering sexual practices only with HIVnegative partners, participants in the intervention group showed significantly lower mean rates of unprotected intercourse at 3 months $(\mathrm{OR}=0.2$; 95\%CI: $-0.22,0.62)$ and 6 months $(\mathrm{OR}=0.8 ; 95 \%$ CI: $-0.34,1.94$ ), but no differences were found in the condom use rate (OR and 95\%CI calculated based on the reported means and standard deviations). Potential moderators of the intervention effects were examined and no main interactions were found, including participant's gender. 
Table 1 (continued)

\begin{tabular}{|c|c|c|c|c|c|}
\hline Study (year)/Place & $\begin{array}{l}\text { Method, time of } \\
\text { study, and follow- } \\
\text { up assessment }\end{array}$ & Population & $\begin{array}{l}\text { Interventions and } \\
\text { comparison conditions }\end{array}$ & $\begin{array}{l}\text { Outcome measures } \\
\text { (condom use } \\
\text { behavior and STIs) ** }\end{array}$ & Notes \\
\hline $\begin{array}{l}\text { Kalichman et al. } 45 \\
\text { (2001)/Atlanta, USA }\end{array}$ & $\begin{array}{l}\text { Parallel RCT; Study } \\
\text { dates not reported; } \\
\text { Immediate post- } \\
\text { intervention, } 3 \text { and } \\
\text { 6-month follow-ups. }\end{array}$ & $\begin{array}{l}328 \text { people living } \\
\text { with HIV (98 } \\
\text { women). Mean } \\
\text { age } 40 \text { years (SD = } \\
\text { 7.0); } 74 \% \text { African } \\
\text { American; } 48 \% \\
\text { had } 12 \text { years of } \\
\text { education; 53\% } \\
\text { currently receiving } \\
\text { disability benefits. } \\
\text { Intervention } \\
\text { group ( } n=185 ; 60 \\
\text { women), Control } \\
\text { group ( } n=143 ; 38 \\
\text { women). }\end{array}$ & $\begin{array}{l}\text { Intervention condition: } \\
\text { Intervention to Reduce HIV- } \\
\text { Transmission Risk consisted } \\
\text { of five 120-minute group } \\
\text { sessions, delivered twice } \\
\text { weekly. Participants were } \\
\text { separately by gender, and } \\
\text { the intervention was based } \\
\text { on Social Cognitive Theory, } \\
\text { aimed at changing high-risk } \\
\text { sexual behaviors through } \\
\text { cognitive and behavioral } \\
\text { skills techniques. Disclosure } \\
\text { situations, barriers, positive } \\
\text { and negative outcomes, and } \\
\text { strategies were discussed } \\
\text { with participants using } \\
\text { role-playing activities. HIV } \\
\text { transmission risks and health } \\
\text { hazards of co-infection with } \\
\text { other STIs were highlighted. } \\
\text { Group discussions included } \\
\text { strategies for maintaining } \\
\text { satisfying and safe } \\
\text { concerns, and nutrition. } \\
\text { relationships, barriers to } \\
\text { condom use, and practice } \\
\text { with male and female } \\
\text { condoms on anatomical } \\
\text { models. Scenes edited from } \\
\text { popular films were used to } \\
\text { elicit participant problem- } \\
\text { solving strategies of risk- } \\
\text { reduction and communication with HIV aimed to } \\
\text { provide updated information } \\
\text { on HIV disease, management } \\
\text { Control condition: The Health } \\
\text { Maintenance Comparison } \\
\text { Intervention consisted of five } \\
\text { group sessions for people } \\
\text { of heare to ART, healthcare } \\
\text { adnute social support }\end{array}$ & $\begin{array}{l}\text { Self-report } \\
\text { questionnaires and } \\
\text { structured interviews. } \\
\text { Condom use for each } \\
\text { partner over 3-month } \\
\text { retrospective period. } \\
\text { Rates of unprotected } \\
\text { and total occasions } \\
\text { of anal and vaginal } \\
\text { intercourse were } \\
\text { analyzed jointly across } \\
\text { partners. Unprotected } \\
\text { oral intercourse was } \\
\text { analyzed separately. } \\
\text { Proportion of } \\
\text { protected anal and } \\
\text { vaginal intercourse } \\
\text { was computed and } \\
\text { HIV transmission } \\
\text { risks to HIV-negative } \\
\text { partners were } \\
\text { estimated. }\end{array}$ & $\begin{array}{l}\text { Several unsuccessful } \\
\text { attempts to contact } \\
\text { authors. Although } \\
\text { study mentioned } \\
\text { moderator analysis } \\
\text { (by gender), it did } \\
\text { not show statistical } \\
\text { significance or } \\
\text { crude results by } \\
\text { gender either } \\
\text { for dichotomous } \\
\text { (consistent condom } \\
\text { use) or continuous } \\
\text { outcome (reduction } \\
\text { in unprotected } \\
\text { sexual acts). }\end{array}$ \\
\hline
\end{tabular}

(continues) 
Table 1 (continued)

\begin{tabular}{|c|c|c|c|c|c|}
\hline Study (year)/Place & $\begin{array}{l}\text { Method, time of } \\
\text { study, and follow- } \\
\text { up assessment }\end{array}$ & Population & $\begin{array}{l}\text { Interventions and } \\
\text { comparison conditions }\end{array}$ & $\begin{array}{l}\text { Outcome measures } \\
\text { (condom use } \\
\text { behavior and STIs) ** }\end{array}$ & Notes \\
\hline $\begin{array}{l}\text { Teti et al. } 44 \text { (2010)/ } \\
\text { Philadelphia, USA }\end{array}$ & $\begin{array}{l}\text { Parallel RCT; April } \\
2004 \text { to July } 2006 \\
\text { (recruitment); 6, } \\
\text { 12, and 18-month } \\
\text { follow-ups. }\end{array}$ & $\begin{array}{l}184 \text { women living } \\
\text { with HIV. Range } 20 \text { - } \\
70 \text { years old; } 86 \% \\
\text { African American; } \\
75 \% \text { low incomes. } \\
\text { Intervention group } \\
\text { ( } n=92) \text {, Control } \\
\text { group ( } n=92) \text {. }\end{array}$ & $\begin{array}{l}\text { Intervention condition: } \\
\text { The intervention group } \\
\text { received messages from } \\
\text { health care providers during } \\
\text { regular scheduled visits, five } \\
\text { 1.5-hour group sessions, } \\
\text { followed by weekly peer-led } \\
\text { support groups. Intervention } \\
\text { strategies were based on } \\
\text { Transtheoretical Model } \\
\text { of Stages of Change, the } \\
\text { Modified AIDS Risk Reduction } \\
\text { Model, and the Theory of } \\
\text { Gender and Power, as well } \\
\text { as on formative research. } \\
\text { Health care providers } \\
\text { assessed participant's stage } \\
\text { of readiness for condom use } \\
\text { and disclosure, delivered } \\
\text { prevention messages, and } \\
\text { create a follow-up plan. } \\
\text { The group sessions focused } \\
\text { on safer sex, sexual risk } \\
\text { reduction approaches, } \\
\text { condom use negotiation } \\
\text { skills, problem-solving, HIV } \\
\text { group intervention and lasted } \\
\text { the length of the project. }\end{array}$ & $\begin{array}{l}\text { Self-report } \\
\text { questionnaires. } \\
\text { Proportion of sexual } \\
\text { acts (vaginal/anal) } \\
\text { where condom was } \\
\text { used with all partners } \\
\text { in the previous } 6 \\
\text { months. }\end{array}$ & $\begin{array}{l}\text { Participants were } \\
\text { not tested for } \\
\text { STIs. Authors were } \\
\text { asked to provide } \\
\text { full information } \\
\text { on continuous } \\
\text { outcome (reduction } \\
\text { in unprotected } \\
\text { sexual acts) and/ } \\
\text { or dichotomous } \\
\text { outcome as well } \\
\text { as sample size } \\
\text { calculation. Authors } \\
\text { replied that they no } \\
\text { longer had access to } \\
\text { the study's database } \\
\text { and could not } \\
\text { provide additional } \\
\text { information. Thus, } \\
\text { the study was not } \\
\text { included in the meta- } \\
\text { analysis. }\end{array}$ \\
\hline & & & $\begin{array}{l}\text { Control condition: The } \\
\text { comparison group received } \\
\text { brief messages delivered by } \\
\text { health care providers during } \\
\text { routine medical visits. }\end{array}$ & & \\
\hline
\end{tabular}

ART: antiretroviral therapy; ARV: antiretrovirals; BV: bacterial vaginosis; CCT: controlled trials; CT: Chlamydia trachomatis; ICC: intraclass correlation coefficient; MOS: Medical Outcomes Study; NG: Neisseria gonorrhoeae; PMTCT: prevention of mother-to-child transmission; RCT: randomized clinical trials; SD: standard deviation; STD: sexually transmitted diseases; STI: sexually transmitted infections; TV: Trichomona vaginalis.

* Summarized information. For complete information, see original references;

** Studies reported multiple outcomes, which may influence condom use (e.g. psychosocial mediators of condom use; partners' HIV status). We highlighted only the outcomes that directly accessed condom use behavior and acquisition of STIs in accordance with the purpose of this systematic review.

Three other interventions were developed exclusively for women living with HIV and tested in the United States 42,43,44. In a quasi-experimental study, Jones et al. 43 reported that at the 3-month assessment, both groups increased male condom use reaching $40 \%$ of protected sexual events in the intervention group $(\mathrm{p}<0.001)$ and $34 \%$ in the comparison $\operatorname{arm}(\mathrm{p}<0.01)$. Nine months post-intervention, no changes in male condom use were observed, but at both the 3-and 9-month assessments it was not 
Figure 2

Risk of bias summary for each included study.

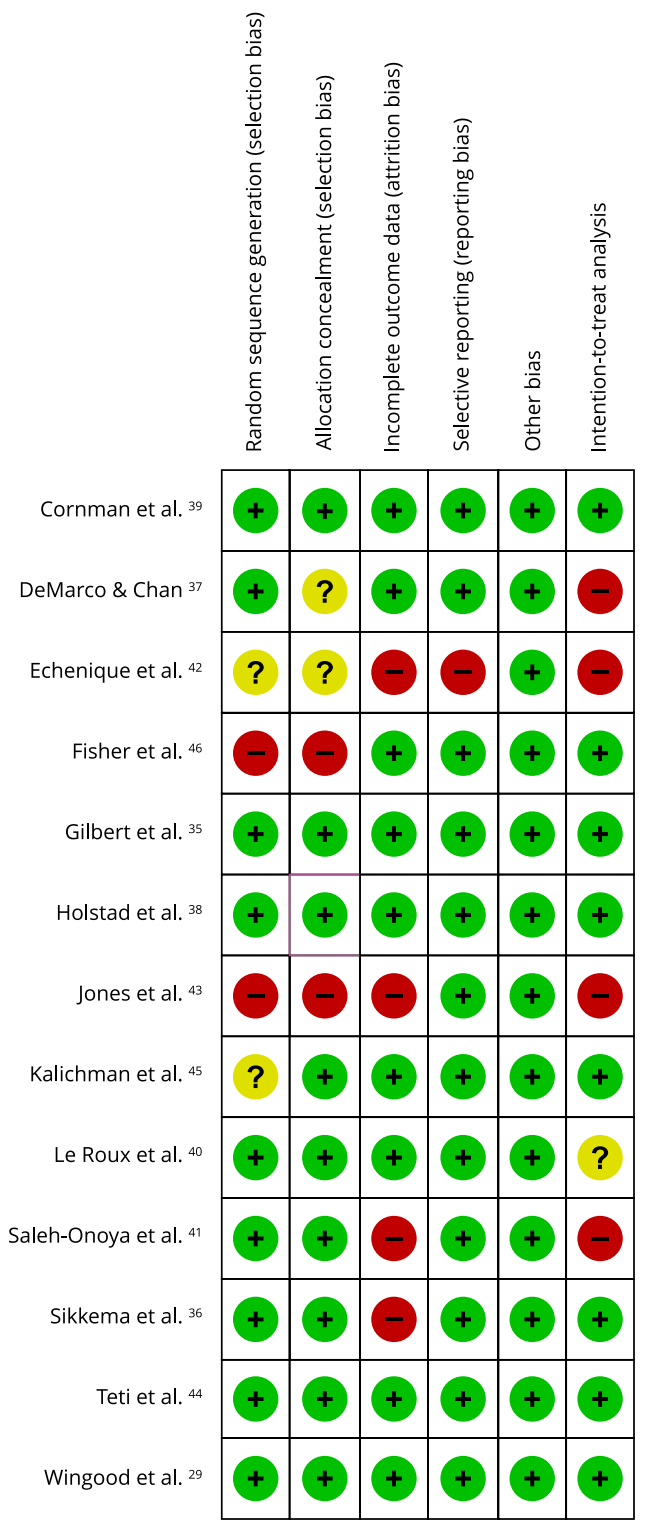

clear if a inter-group analysis had been performed. Using a RCT design and applying only bivariate analysis, Echenique et al. 42 found women living with HIV in the intervention group significantly ( $\mathrm{p}$ $<0.05$ ) reduced inconsistent condom use with all partners from baseline (20\%) to 6-month follow-up (9.2\%), while women in the control group did not. Finally, another RCT 44 reported that intervention participants were more likely to report condom use at 6 months (AOR = 17.13; 95\%CI: 2.96, 99.10; p $<0.01$ ) and 18 months (AOR = 270.04; 95\%CI: 24.53, 2,971.94; p < 0.01). 


\section{Figure 3}

Effectiveness of behavioral intervention versus standard care or minimal HIV support treatment in consistent condom use.

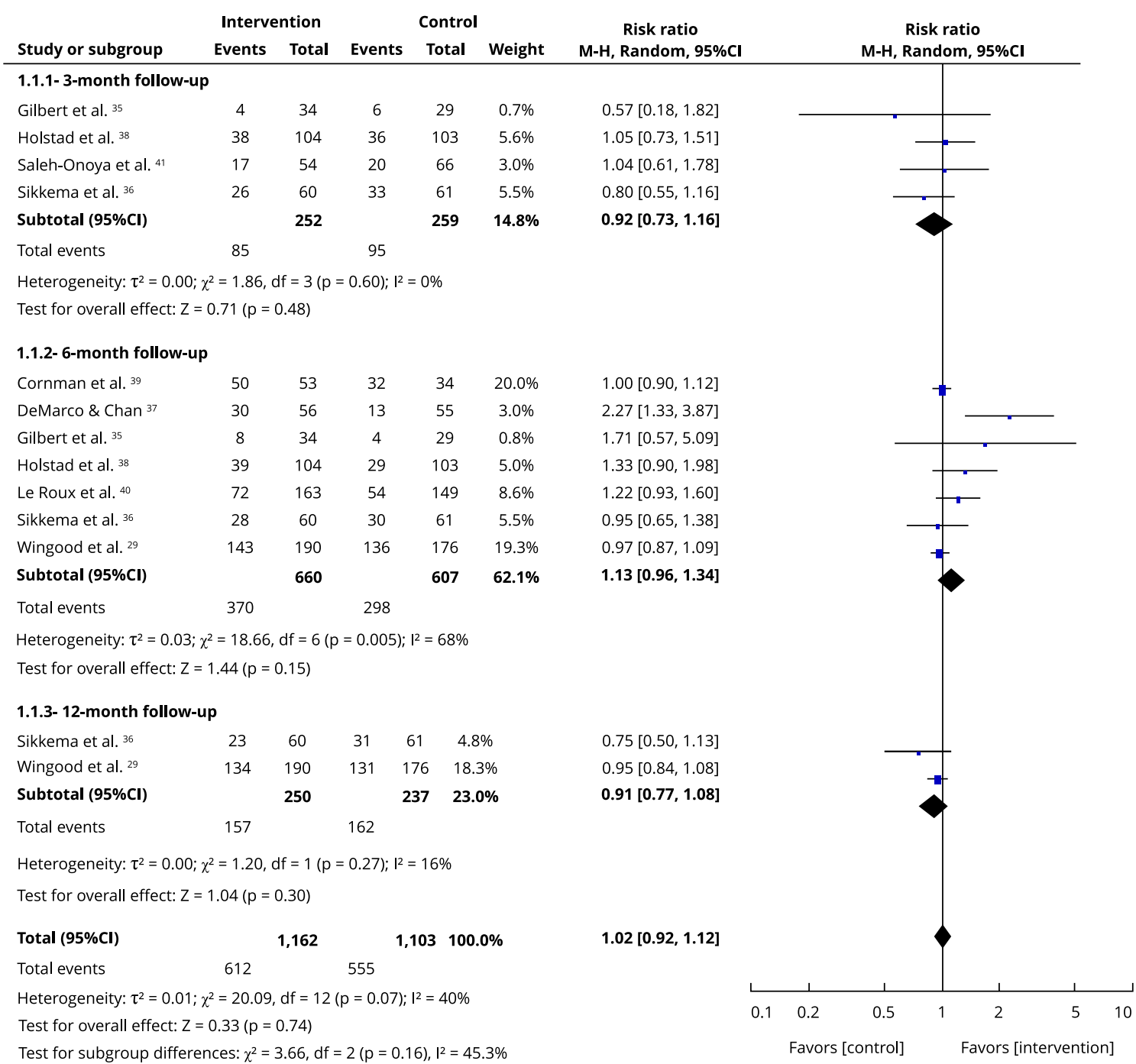

95\% Cl: 95\% confidence interval.

\section{Discussion}

A previous systematic review and meta-analysis on behavioral interventions to promote condom use among women living with HIV was not able to demonstrate positive effects 30 . Considering the need for a more accurate picture of these interventions and their implications for research and decisionmaking in public health, this study aimed to update and broaden the previous review, including newly published studies and adding a continuous outcome to the pooled analysis.

Concerning consistent condom use (dichotomous outcome), this updated version was unable to identify effects of behavioral interventions even after including other studies, maintaining the result of the original meta-analysis 30 . As suggested previously 30, we included a less rigorous outcome in the quantitative syntheses which was intended to identify a reduction in unprotected sexual acts and 
Figure 4

Effectiveness of behavioral intervention versus standard care or minimal HIV support treatment in reducing unprotected sexual intercourse.

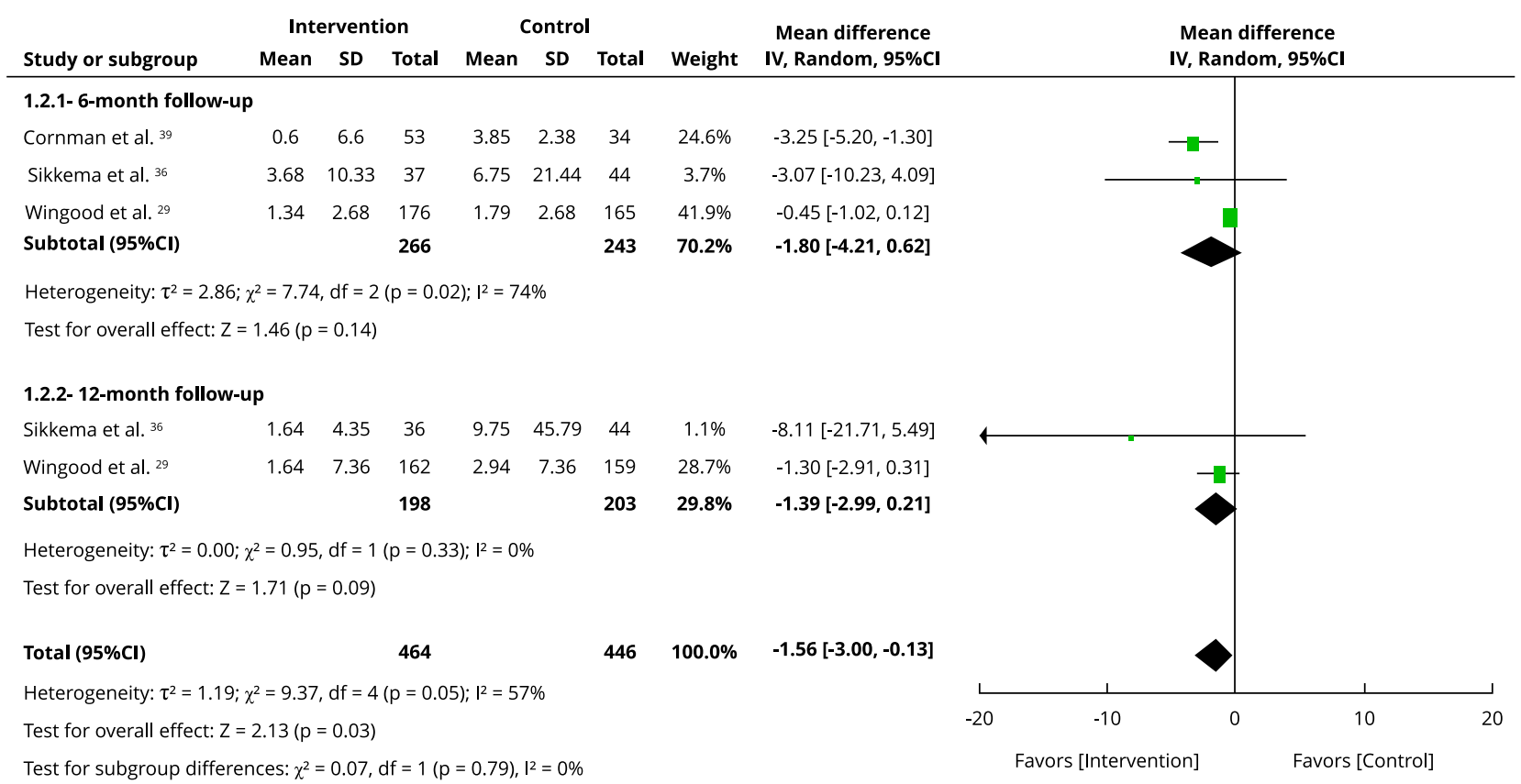

95\%Cl: 95\% confidence interval.

an increase in the frequency of condom use. Contrary to expectations, the inclusion of a continuous outcome in the updated review did not show positive intervention effects, thus corroborating a growing body of evidence showing low efficacy of behavioral interventios to prevent STI 54. Even adding some studies in this updated version, we found that data are still limited on the effects of behavioral inteventions on condom use among women living with HIV, and are based on small studies. Thus, our results might change when findings from larger studies are included.

Recent debates have questioned whether biomedical trial methods are the most fitting for assessing behavioral inteventions 18 . Behavioral change is a complex and highly context-dependent phenomenon, in contrast to biomedical outcomes which are more objective and easier to measure and respond to - for example, morbidity assessed through blood tests or self-reported symptoms. According to Joint United Nations Programme on HIV/AIDS (UNAIDS) 18, behavioral change interventions appear to be difficult to evaluate through RCTs and can be erroneously interpreted as ineffective. Still, behavioral change has been responsible for important early declines in HIV incidence in several countries with generalized epidemics 18. Promoting consistent condom use is still a central public health strategy to stop ongoing transmission and avoid negative effects of multiple sexually transmitted infections and/or superinfection in people living with HIV, especially in resource-limited settings where antiretroviral therapy is not widely accessible. The potentially false idea that behavioral interventions do not work could be overcome by carefully examining contextual aspects and designing studies with better methodological quality.

Contrary to findings in the meta-analysis, a different picture emerged when we examined the qualitative syntheses. Different statistical approaches conducted individually by each study showed positive results in all but one intervention 41 , either considering consistent condom use and/or reducing the proportion of unprotected sexual acts. These discordant findings are probably related to the intention-to-treat approach assumed in the pooled analyses instead of the per-protocol analysis adopted by most of the studies. 
Regarding reduction of STI incidence in women living with HIV, two studies individually mentioned favorable effects of behavioral interventions, but the results could not be pooled in a metaanalysis. STI diagnosis is a critical public health outcome in behavioral intervention trials, since solid evidence backs the biological pathways by which STI facilitate HIV transmission and the negative effects of multiple sexually transmitted infections, especially in women living with HIV 4,5,53. We therefore emphasize that even small reductions in STI incidence could favor critical reductions in HIV morbidity and its associated treatment cost. Future behavioral interventions should include STI reduction among their main outcomes in order to better examine their effects.

Another key issue is that few RCTs were found with available data to evaluate the effects of interventions on condom use according to gender. Furthermore, behavioral interventions especially tailored for condom use promotion among women living with HIV are still scarce, which could explain why subgroup analyses could not find differences in intervention effects, based on whether they were exclusively tailored for women. Despite repeated research findings indicating the challenges faced by women living with HIV, more studies are needed to understand how gender-linked factors (e.g., skill-building to negotiate condom use, gender violence, and gender power imbalances regarding economic resources and employment) influence the effectiveness of behavioral interventions to promote condom use 16,54,55. A recent systematic review of behavioral interventions to improve contraceptive use for family planning among women living with HIV also found limited evidence to compare the interventions' results 56. Among seven included studies, all in Africa, new use of condoms was more likely in women attending services delivering multi-level and integrated care compared to those in routine care in one study. The authors highlighted the lack of effectiveness of delivering standardized information compared to interventions focused on the specific needs and concerns of women living with HIV regarding family planning.

In addition, none of the included studies explicitly mentioned promotion of female condom use, implying that male condoms were the intervention target. This could be seen as an important limitation to such interventions, since male condoms are not a female-initiated contraceptive method. Therefore, interventions involving female condoms should be promoted. We also endorse and advocate interventions to promote pleasant and empowered settings for female and/or male condom use, especially among women living with HIV. Future studies should also try to better elucidate the diversity across women living with HIV, dealing with heterogeneous intervention effects, for example, among women planning to become pregnant, women with casual versus steady partners, women with seroconcordant or serodiscordant partners, and women with multiple partners. Such research would be useful for understanding how specific groups of women could take advantage of interventions to promote condom use as well as for identifying new strategies for designing interventions.

We recommend that behavioral interventions focusing on condom use promotion among women living with HIV could have greater public health impact if they were part of broad positive prevention programs delivered with a gender perspective (including women-initiated prevention options) and developing actions that involve male partners, family planning counseling, community empowerment, mental health and drug abuse treatment, and safe serostatus disclosure settings 11,55 . As seen in the qualitative syntheses, few studies included issues beyond sexual risk behavior and none approached family planning or included women's partners. We agree that without addressing social and cultural norms that shape sexual behaviors, opportunities for individual-level behavioral change are limited 18. A new approach to assessment of interventions' effect on condom use in women living with HIV should thus include mediator and moderator factors that assess broad social norms and diversified cultural contexts where sexual practices take place as well as access to specialized and primary healthcare services.

The review process was minimally biased since searches were not restricted by language and included a comprehensive search of databases, conference proceedings, and trials registers as well as contact with experts. The same search strategy and inclusion criteria were applied in both versions. Still, the present systematic review has some limitations that need to be examined. The review's first version had a specific protocol 30 while the present version did not, which could introduce bias. Even so, some of the analyses in the present version were included in the original protocol (e.g., subgroup analysis) as well as in the discussion of results in the first review (e.g., inclusion of a continuous 
outcome). In addition, some eligible studies 42,43,44,45 lacked data for inclusion in the meta-analyses, which may have affected the effect size estimates.

Most of the studies were based in clinics where participants were receiving regular HIV care and do not accurately reflect women living with HIV as a whole. No study included in the review had an adequate number of female participants, emphasizing the importance of further research with larger female sample sizes. Meta-analysis also assumes that interventions are sufficiently similar to be combined, while behavioral interventions entail some dissimilarity, which makes it more difficult to propose strict recommendations. Finally, condom use is a multi-causal outcome demanding multimodal and multilevel interventions 18. Evaluating behavior change interventions requires understanding how individuals perceive HIV risk and the ability to protect themselves, including knowledge of the available choices.

After assessing data on interventions in female participants following participation in behavioral interventions, we were unable to identify either increases in consistent condom use or reduction in unprotected sex among women living with HIV. In order to capture intervention effects on condom use among women, we strongly recommend multi-method evaluations involving HIV incidence modeling, meta-analyses, and surveys on behavioral and service utilization trends, as well as ethnographical and qualitative clinical trials.

\section{Contributors}

T. R. Gonçalves participated in the study concept and design, conducted the study search, performed the analyses, worked on the article selection and data extraction, and drafted and critically revised the manuscript. E. R. Faria and F. T. Carvalho participated in the study concept and design, worked on the article selection and data extraction, and drafted and critically revised the manuscript. C. A. Piccinini and J. A. Shoveller participated in the study concept and design, wrote part of the discussion section, and critically revised the manuscript.

\section{Acknowledgments}

The authors wish to thank the Brazilian National Research Council (CNPq), the Brazilian Ministry of Health, and the Rio Grande do Sul State Research Foundation (FAPERGS) for their financial support. Thanks also to Haschi Horvath and Andrew Anglemyer for the statistical advice and an anonymous reviewer for his/her careful review. FAPERGS - Call for Projects ARD/2013 and CNPq - Call for Projects n. 37/2008 MCT/MS. 


\section{References}

1. World Health Organization. Global summary of the HIV/AIDS epidemic 2014. http://www.who. int/hiv/data/epi_core_july2015.png?ua=1.

2. Harrison A, Colvin CJ, Kuo C, Swartz A, Lurie M. Sustained high HIV incidence in young women in Southern Africa: social, behavioral, and structural factors and emerging intervention approaches. Curr HIV/AIDS Rep 2015; 12:207-15.

3. Ministério da Saúde. Boletim epidemiológico AIDS/DST 2014. Brasília: Ministério da Saúde; 2014.

4. Landes M, Thorne C, Barlow P, Fiore S, Malyuta R, Martinelli $\mathrm{P}$, et al. Prevalence of sexually transmitted infections in HIV-1 infected pregnant women in Europe. Eur J Epidemiol 2007; 22:925-36.

5. McClelland RS, Lavreys L, Katingima C, Overbaugh J, Chohan V, Mandaliya K, et al. Contribution of HIV-1 infection to acquisition of sexually transmitted disease: a 10-year prospective study. J Infect Dis 2005; 191:333-8.

6. Lehtovirta P, Paavonen J, Heikinheimo O. Risk factors, diagnosis and prognosis of cervical intraepithelial neoplasia among HIV-infected women. Int J STD AIDS 2008; 19:37-41.

7. Oliveira PM, Oliveira RP, Travessa IE, Gomes MV, Santos ML, Grassi MF. Prevalence and risk factors for cervical intraepithelial neoplasia in HIV-infected women in Salvador, Bahia, Brazil. São Paulo Med J 2010; 128:197-201.

8. Departamento de DST, Aids e Hepatites Virais, Secretaria de Vigilância em Saúde, Ministério da Saúde. Recomendações para profilaxia da transmissão vertical do HIV e terapia antirretroviral em gestantes. Brasília: Ministério da Saúde; 2010.

9. World Health Organization; Joint United Nations Programme on HIV/AIDS; United Nations Population Fund. Position statement on condoms and HIV prevention, 2014. Geneva: World Health Organization; 2014.

10. Joint United Nations Programme on HIV/AIDS. " 15 by 15 " - a global target achieved. Geneva: Joint United Nations Programme on HIV/AIDS; 2015.

11. Weeks MR, Zhan W, Li J, Hilario H, Abbott M, Medina $\mathrm{Z}$. Female condom use and adoption among men and women in a general low-income urban U.S. population. AIDS Behav 2015; 19:1642-54.
12. Shuper PA, Kiene SM, Mahlase G, MacDonald S, Christie S, Cornman DH, et al. HIV transmission risk behavior among HIV-positive patients receiving antiretroviral therapy in KwaZulu-Natal, South Africa. AIDS Behav 2014; 18:1532-40.

13. Cicconi P, Monforte A, Castagna A, Quirino T, Alessandrini A, Gargiulo M, et al. Inconsistent condom use among HIV-positive women in the "Treatment as Prevention Era": data from the Italian DIDI study. J Int AIDS Soc 2013; 16:18591.

14. Weinhardt LS, Kelly JA, Brondino MJ, RotheramBorus MJ, Kirshenbaum SB, Chesney MA, et al. HIV transmission risk behavior among men and women living with HIV in 4 cities in the United States. J Acquir Immune Defic Syndr 2004; 36:1057-66.

15. Wilson TE, Gore ME, Greenblatt R, Cohen M, Minkoff $\mathrm{H}$, Silver S, et al. Changes in sexual behavior among HIV-infected women after initiation of HAART. Am J Public Health 2004; 94:1141-6.

16. Santos NJ, Barbosa RM, Pinho AA, Villela WV, Aidar T, Filipe EMV. Contextos de vulnerabilidade para o HIV entre mulheres brasileiras. Cad Saúde Pública 2009; 25 Suppl 2:S321-33.

17. Finocchario-Kessler S, Sweat MD, Dariotis JK, Trent ME, Kerrigan DL, Keller JM, et al. Understanding high fertility desires and intentions among a sample of urban women living with HIV in the United States. AIDS Behav 2010; 14:110614.

18. Joint United Nations Programme on HIV/AIDS. Social and behaviour change programming. Geneva: Joint United Nations Programme on HIV/ AIDS; 2014

19. Scott-Sheldon LAJ, Huedo-Medina TB, Warren MR, Johnson BT, Carey MP. Efficacy of behavioral interventions to increase condom use and reduce sexually transmitted infections: a meta-analysis, 1991 to 2010. J Acquir Immune Defic Syndr 2011; 58:489-98.

20. Faria ER, Carvalho FT, Gonçalves TR, Moskovics JM, Piccinini CA. Intervenções psicológicas para pessoas vivendo com HIV/Aids: modelos, resultados e lacunas. Interam J Psychol 2011; 45:339-50. 
21. Crepaz N, Lyles CM, Wolitski RJ, Passin WF, Rama $\mathrm{SM}$, Herbst JH, et al. Do prevention interventions reduce HIV risk behaviours among people living with HIV? A meta-analytic review of controlled trials. AIDS 2006; 20:143-57.

22. Johnson MO, Charlebois E, Morin SF, Remien RH, Chesney MA; The NIMH Healthy Living Project Team. Effects of a behavioral intervention on antiretroviral medication adherence among people living with HIV: the Healthy Living Project randomized controlled study. J Acquir Immune Defic Syndr 2007; 46:574-80.

23. Serovich JM, Reed S, Grafsky EL, Andrist D. An intervention to assist men who have sex with men disclose their serostatus to casual sex partners: results from a pilot study. AIDS Educ Prev 2009; 21:207-19.

24. Balfour L, Kowal J, Silverman A, Tasca GA, Angel JB, Macpherson PA, et al. A randomized controlled psycho-education intervention trial: improving psychological readiness for successful HIV medication adherence and reducing depression before initiating HAART. AIDS Care 2006; 18:830-8.

25. Gore-Felton C, Rotheram-Borus MJ, Weinhardt LS, Kelly JA, Lightfoot M, Kirshenbaum SB, et al. The Healthy Living Project: an individually tailored, multidimensional intervention for HIV-infected persons. AIDS Educ Prev 2005; 17:21-39.

26. Healthy Living Project Team. Effects of a behavioral intervention to reduce risk of transmission among people living with HIV: the Healthy Living Project randomized controlled study. J Acquir Immune Defic Syndr 2007; 44:213-21.

27. Johnson BT, Carey MP, Chaudoir SR, Reid AE. Sexual risk reduction for persons living with HIV: research synthesis of randomized controlled trials, 1993 to 2004. J Acquir Immune Defic Syndr 2006; 41:642-50.

28. Wyatt GE, Longshore D, Chin D, Carmona JV, Loeb TB, Myers HF, et al. The efficacy of an integrated risk reduction intervention for HIVpositive women with child sexual abuse histories. AIDS Behav 2004; 8:453-62.

29. Wingood GM, DiClemente RJ, Mikhail I, Lang DL, McCree DH, Davies SL, et al. A randomized controlled trial to reduce HIV transmission risk behaviors and sexually transmitted diseases among women living with HIV: the WiLLOW Program. J Acquir Immune Defic Syndr 2004; 37:S58-67.
30. Carvalho FT, Goncalves TR, Faria ER, Shoveller JA, Piccinini CA, Ramos MC, et al. Behavioral interventions to promote condom use among women living with HIV. Cochrane Database Syst Rev 2011; (9):CD007844.

31. Higgins JPT, Green SP. Cochrane handbook for systematic reviews of interventions. Version 5.0.0 Chichester: John Wiley; 2008.

32. GRADE Working Group. Grading quality of evidence and strength of recommendations. BMJ 2004; 328:1490.

33. Guyatt G, Oxman AD, Akl EA, Kunz R, Vist G, Brozek J, et al. GRADE guidelines: 1. Introduction - GRADE evidence profiles and summary of findings tables. J Clin Epidemiol 2011; 64:383-94.

34. Rotheram-Borus MJ, le Roux IM, Tomlinson M, Mbewu N, Comulada WS, le Roux K, et al. Philani Plus (+): a Mentor Mother community health worker home visiting program to improve maternal and infants' outcomes. Prev Sci 2011; 12:372-88.

35. Gilbert P, Ciccarone D, Gansky SA, Bangsberg DR, Clanon K, McPhee SJ, et al. Interactive "Video Doctor" counseling reduces drug and sexual risk behaviors among HIV-positive patients in diverse outpatient settings. PLoS One 2008; 3:e1988.

36. Sikkema KJ, Wilson PA, Hansen NB, Kochman A, Neufeld S, Ghebremichael MS, et al. Effects of a coping intervention on transmission risk behavior among people living with HIV/AIDS and a history of childhood sexual abuse. J Acquir Immune Defic Syndr 2008; 47:506-13.

37. DeMarco RF, Chan K. The Sistah Powah structured writing intervention: a feasibility study for aging, low-income, HIV-positive black women. Am J Health Promot 2013; 28:108-18.

38. Holstad MM, Dilorio C, Kelley ME, Resnicow K, Sharma S. Group motivational interviewing to promote adherence to antiretroviral medications and risk reduction behaviors in HIV infected women. AIDS Behav 2011; 15:885-96.

39. Cornman DH, Kiene SM, Christie S, Fisher WA, Shuper PA, Pillay S, et al. Clinic-based intervention reduces unprotected sexual behavior among HIV-infected patients in KwaZulu-Natal, South Africa: results of a pilot study. J Acquir Immune Defic Syndr 2008; 48:553-60. 
40. Le Roux IM, Tomlinson M, Harwood JM, O'Connor MJ, Worthman CM, Mbewu N, et al. Outcomes of home visits for pregnant mothers and their infants: a cluster randomized controlled trial. AIDS 2013; 27:1461-71.

41. Saleh-Onoya D, Reddy PS, Ruiter RA, Sifunda S, Wingood G, van den Borne B. Condom use promotion among isiXhosa speaking women living with HIV in the Western Cape Province, South Africa: a pilot study. AIDS Care 2009; 21:817-25.

42. Echenique M, Illa L, Saint-Jean G, Avellaneda VB, Sanchez-Martinez M, Eisdorfer C. Impact of a secondary prevention intervention among HIVpositive older women. AIDS Care 2013; 25:443-6.

43. Jones DL, Weiss SM, Malow R, Ishii M, Devieux J, Stanley $\mathrm{H}$, et al. A brief sexual barrier intervention for women living with AIDS: acceptability, use, and ethnicity. J Urban Health 2001; 78:593-604.

44. Teti M, Bowleg L, Cole R, Lloyd L, Rubinstein S, Spencer S, et al. A mixed methods evaluation of the effect of the Protect and Respect intervention on the condom use and disclosure practices of women living with HIV/AIDS. AIDS Behav 2010; 14:567-79.

45. Kalichman SC, Rompa D, Cage M, DiFonzo K, Simpson D, Austin J, et al. Effectiveness of an intervention to reduce HIV transmission risks in HIV-positive people. Am J Prev Med 2001; 21:84-92.

46. Fisher JD, Fisher WA, Cornman DH, Amico RK, Bryan A, Friedland GH. Clinician-delivered intervention during routine clinical care reduces unprotected sexual behavior among HIV-infected patients. J Acquir Immune Defic Syndr 2006; 41:44-52.

47. Kalichman SC. Behavioral intervention to enhance HIV test/treat. https:/clinicaltrials.gov/ct2/show/ NCT01752777 (accessed on 24/Nov/2016).

48. Kidder DP, Bachanas P, Medley A, Pals S, Nuwagaba-Biribonwoha $\mathrm{H}$, Ackers $\mathrm{M}$, et al. HIV prevention in care and treatment settings: baseline risk behaviors among HIV patients in Kenya, Namibia, and Tanzania. PLoS One 2013; 8:e57215.
49. Wilson MM, Frimpong S, McLaughlin G, Hilliard A, Seaman L, Mitchell-Samon LM, et al. The Interdiction Project (TIP) phase I-III: a potential innovation program for HIV-positive persons to reduce STD co-infection with HIV/AIDS, new HIV infection and resistant HIV transmission. In: 19th International AIDS Conference. http://www. abstract-archive.org/.

50. Guo Y, Su B. A research report on "positive prevention" intervention in two ethnic habitats along the border with Myanmar in Yunnan. Retrovirology 2010; 7:P96.

51. Hulley SB, Cummings SR, Browner WS, Grady D, Hearst N, Newman TB. Designing clinical research. 2nd Ed. Philadelphia: Lippincott Williams \& Wilkins; 2001.

52. Sterne JA, Egger M, Smith GD. Systematic reviews in health care: Investigating and dealing with publication and other biases in meta-analysis. BMJ 2001; 323:101-5.

53. Lopes F, Buchalla CM, Ayres JRCM. Mulheres negras e não-negras e vulnerabilidade ao HIV/AIDS no estado de São Paulo, Brasil. Rev Saúde Pública 2007; 41:39-46.

54. Macaya Pascual A, Ferreres Riera JR, Campoy Sánchez A. Behavioral interventions for preventing sexually transmitted infections and unintended pregnancies: an overview of systematic reviews. Actas Dermo-Sifiliográficas (English Edition) 2016; 107:301-17.

55. Chakrapani V, Newman PA, Shunmugam M, Dubrow R. Prevalence and contexts of inconsistent condom use among heterosexual men and women living with HIV in India: implications for prevention. AIDS Patient Care STDS 2010; 24:49-58.

56. Lopez LM, Hilgenberg D, Chen M, Denison J, Stuart G. Behavioral interventions for improving contraceptive use among women living with HIV. Cochrane Database Syst Rev 2013; (1):CD010243. 


\section{Resumo}

As intervenções comportamentais têm sido componentes essenciais das abordagens de prevenção do $H I V$, especialmente daquelas que visam promover práticas sexuais seguras. Realizamos uma pesquisa bibliográfica abrangente sem restrições de linguagem entre 1980 e julho de 2014, visando identificar ensaios randomizados e não randomizados que investigassem intervenções comportamentais que: incluíssem mulheres vivendo com HIV; focassem na promoção do uso de preservativo; apresentassem ou analizassem resultados por gênero; realizasse acompanhamento por três meses ou mais; e considerasse pelo menos um resultado comportamental ou biológico relacionado ao HIV. Oito estudos com um total de 1.355 mulheres vivendo com HIV foram incluídos nas meta-análises e 13 estudos foram qualitativamente descritos. Quando comparadas com o tratamento padrão ou intervenção mínima de apoio, as intervenções comportamentais não demonstraram efeito no aumento do uso do preservativo no seguimento de 3 meses $(R R=0,92 ;$ IC95\%: 0,73, 1,16; $p=0,48)$, no seguimento de 6 meses $(R R=1,13$; IC95\%: 0,96, 1,34; $p=0,15)$, e no seguimento de 12 meses $(R R=0,91$; IC95\%: 0,77, 1,08; $p=0,30$ ). Intervenções comportamentais também não demonstraram efeito positivo na redução de relações sexuais desprotegidas aos 6 meses (MD =-1,80; IC95\%: -4,21, 0,62; $p=$ $0,14)$ e aos 12 meses de seguimento $(M D=-1,39$; IC95\%: -2,29, 0,21; $p=0,09)$. Estes resultados devem ser interpretados com cautela, uma vez que se baseiam em poucos estudos. São necessárias novas pesquisas para avaliar os potenciais ganhos de uma combinação de intervenções que promovam comportamentos sexuais seguros, com uma abordagem de gênero e de redução de danos, particularmente em paises em desenvolvimento onde as taxas de infecção pelo HIV permanecem altas.

Ensaio Clínico; Comportamento Sexual; HIV; Mulheres

\section{Resumen}

Las intervenciones comportamentales han sido componentes esenciales de los enfoques de prevención del VIH, especialmente de aquellos que tienen por objetivo promover prácticas sexuales seguras. Realizamos una investigación bibliográfica amplia, sin restricciones de lengua, entre 1980 y julio de 2014, teniendo por objetivo identificar ensayos randomizados controlados o estudios controlados que investigaran intervenciones comportamentales que: incluyeran a mujeres viviendo con VIH; se enfocaran en la promoción del uso de preservativo; presentaran o analizaran resultados por género; realizara un seguimiento durante tres meses o más; y considerara -por lo menos- un resultado comportamental o biológico relacionado con el $V I H$. Ocho estudios con un total de 1.355 mujeres viviendo con VIH se incluyeron en los metaanálisis y 13 estudios fueron cualitativamente descritos. Cuando se comparan con el tratamiento patrón o intervención mínima de apoyo, las intervenciones comportamentales no demostraron un efecto en el aumento del uso del preservativo en el seguimiento de 3 meses ( $R R=0$,92; IC95\%: 0,73, 1,16; $p=0,48)$, en el seguimiento de 6 meses $(R R=1,13$; IC95\%: 0,96, 1,34; $p=0,15)$, y en el seguimiento de 12 meses $(R R=0,91$; IC95\%: 0,77, 1,08; $p=$ 0,30 ). Las intervenciones comportamentales tampoco demostraron un efecto positivo en la reducción de relaciones sexuales desprotegidas a los 6 meses (MD =-1,80; IC95\%: -4,21, 0,62; $p=0,14$ ) $y$ a los 12 meses de seguimiento $(M D=-1,39$; IC95\%: -2,29, 0,21; $p=0,09)$. Estos resultados deben ser interpretados con cautela, ya que se basan en pocos ensayos. Es necesaria una nueva investigación para evaluar las potenciales ganancias de una combinación de intervenciones que promuevan comportamientos sexuales seguros, con un enfoque de género y de reducción de daños, particularmente en países en desarrollo, donde las tasas de infección por el VIH permanecen altas.

Ensayo Clínico; Conducta Sexual; VIH; Mujeres
Submitted on 09/Dec/2015

Final version resubmitted on 12/Sep/2016

Approved on 25/Oct/2016 